OPEN ACCESS

Edited by:

Alexandrina L. Dumitrescu,

Dental Private Practice, Romania

Reviewed by:

Xiao-feng Yang

Temple University School of Medicine,

United States

Houzao Chen,

University of Chinese Academy of

Sciences (UCAS), China

${ }^{*}$ Correspondence:

Srijit Das

drsrijit@gmail.com

Specialty section:

This article was submitted to

Oxidant Physiology,

a section of the journal

Frontiers in Physiology

Received: 04 July 2017

Accepted: 29 August 2017

Published: 14 September 2017

Citation:

Kumar J, Teoh SL, Das S and Mahakknaukrauh P (2017) Oxidative

Stress in Oral Diseases: Understanding Its Relation with Other

Systemic Diseases.

Front. Physiol. 8:693.

doi: 10.3389/fphys.2017.00693

\section{Oxidative Stress in Oral Diseases: Understanding Its Relation with Other Systemic Diseases}

\author{
Jaya Kumar ${ }^{1}$, Seong Lin Teoh ${ }^{2}$, Srijit Das ${ }^{2 *}$ and Pasuk Mahakknaukrauh ${ }^{3,4,5}$ \\ ${ }^{1}$ Department of Physiology, Universiti Kebangsaan Malaysia Medical Centre, Kuala Lumpur, Malaysia, ${ }^{2}$ Department of \\ Anatomy, Universiti Kebangsaan Malaysia Medical Centre, Kuala Lumpur, Malaysia, ${ }^{3}$ Forensic Osteology Research, Chiang \\ Mai University, Chiang Mai, Thailand, ${ }^{4}$ Excellence in Osteology Research and Training Center, Chiang Mai University, Chiang \\ Mai, Thailand, ${ }^{5}$ Department of Anatomy, Faculty of Medicine, Chiang Mai University, Chiang Mai, Thailand
}

Oxidative stress occurs in diabetes, various cancers, liver diseases, stroke, rheumatoid arthritis, chronic inflammation, and other degenerative diseases related to the nervous system. The free radicals have deleterious effect on various organs of the body. This is due to lipid peroxidation and irreversible protein modification that leads to cellular apoptosis or programmed cell death. During recent years, there is a rise in the oral diseases related to oxidative stress. Oxidative stress in oral disease is related to other systemic diseases in the body such as periodontitis, cardiovascular, pancreatic, gastric, and liver diseases. In the present review, we discuss the various pathways that mediate oxidative cellular damage. Numerous pathways mediate oxidative cellular damage and these include caspase pathway, PERK/NRF2 pathway, NADPH oxidase 4 pathways and JNK/mitogen-activated protein (MAP) kinase pathway. We also discuss the role of inflammatory markers, lipid peroxidation, and role of oxygen species linked to oxidative stress. Knowledge of different pathways, role of inflammatory markers, and importance of low-density lipoprotein, fibrinogen, creatinine, nitric oxide, nitrates, and highly sensitive C-reactive proteins may be helpful in understanding the pathogenesis and plan better treatment for oral diseases which involve oxidative stress.

Keywords: oral, disease, oxidative stress, pathways, free radicals, inflammation

\section{OXIDATIVE STRESS AND RELATED DISEASES IN THE BODY}

Oxidative stress occurs as a state of disturbance between free radical produced and the capability of antioxidant system to counteract such (Pisoschi and Pop, 2015). Free radicals are also classified as reactive oxygen species (ROS) or reactive nitrogen species (RNS) and both possess unpaired valence electrons. ROS can be further classified into oxygen centered radicals (superoxide anion, hydroxyl radicals, alkoxyl radicals, and peroxyl radicals) and oxygen centered non-radicals (hydrogen peroxide and singlet oxygen), while RNS consists of nitric oxide, nitric dioxide and peroxynitrite (El-Bahr, 2013). ROS are naturally occurring oxidants involved in numerous cellular biochemical events that are essential to life but at the same time capable of causing harmful oxidative stress when overproduced (McCord, 2000). Free radicals cause damage to all essential biocompounds such as DNA, proteins, and membrane lipids, thereby causing cause cell death. These free radicals are countered by inherent antioxidant system that exists in two major groups: enzymatic 
(glutathione peroxidase, myeloperoxidase, superoxide dismutase, and catalase) and non-enzymatic (minerals, vitamins, polyphenols, and thiols; Gilgun-Sherki et al., 2001; Pisoschi and Pop, 2015).

Oxidative stress forms the basis of cancer, diabetes, rheumatoid arthritis, non-alcoholic fatty liver disease, chronic inflammation, stroke, aging, and numerous neurodegenerative diseases (Fridovich, 1999; Fang et al., 2002; Gentric et al., 2015; Pisoschi and Pop, 2015). Different epidemiological and clinical studies showed evidence of important role of oxidative stress and impairment of antioxidant defense systems in the pathogenesis, neoangiogenesis, and dissemination of local or distant cancers, such as cancers of the ovary and prostate (Oh et al., 2016; Saed et al., 2017). In any cancer, oxidative stress induced by hypoxia, was reported to promote oncogenic protein (MUC4) degradation via autophagy, enhancing the survival of cancer cells in the pancreas (Joshi et al., 2016). In Parkinson's disease, oxidative stress and aggregation of protein are the key pathogenic processes, where aggregation of $\alpha$-synuclein results in aberrant free radical production and neuronal death (Deas et al., 2016). Similarly in Alzheimer's disease, amyloid- $\beta$ inserts into the membrane systems to begin the oxidative stress during the disease progression in the brain (Swomley and Butterfield, 2015). In addition, increased oxidative stress and reduced superoxide dismutase levels were observed in human peripheral blood mononuclear cells which were obtained from patients with mild cognitive impairment (Mota et al., 2015).

\section{OXIDATIVE STRESS RELATED TO ORAL DISEASES}

Oral diseases such as periodontitis, dental caries, cancer in the oral cavity, HIV/AIDS, diseases involving mucosal and salivary glands, orofacial pain, and clefts, affect the oral health and hygiene (Jin et al., 2016). Global Burden of Disease 2015 study showed individuals with untreated oral conditions to increase from 2.5 billion in the year 1990 to 3.5 billion in 2015, with a $64 \%$ increase in disabilityadjusted life year (Kassebaum et al., 2017). In addition, the direct and indirect treatment expenses due to dental diseases worldwide, were approximately US $\$ 442$ billion in 2010 (Listl et al., 2015).

Among all oral diseases, the periodontal disease (comprising gingivitis and periodontitis), accounted for 3.5 million years lived with disability, US $\$ 54$ billion/year in lost productivity and a major portion of the US $\$ 442$ billion/year cost for oral diseases (Tonetti et al., 2017). Oxidative stress was involved in the progression of periodontitis, a chronic inflammatory disease of the periodontal tissue, caused by disturbance in the regulation of the host inflammatory in response to bacterial infection (Kataoka et al., 2016; Kanzaki et al., 2017). In chronic periodontitis, there was lower serum total antioxidant level and salivary capacity when compared to the control individuals (Ahmadi-Motamayel et al., 2017). Biomarkers of lipid peroxidation (one of the oxidative stress-mediated pathways) such as 8-isoprostane and malondialdehyde (MDA) were high in patients affected by chronic periondontitis (Akalin et al., 2007; Matthews et al., 2007; Pradeep et al., 2013). In addition, assessment of blood and gingival tissues of chronic periodontitis patients also revealed mitochondrial DNA deletion (5 kbp; Canakci et al., 2006). Gingival blood analysis of periodontitis patients also marked high level of 7-8-dihydro8 -ossiguanina (8-oxoG), a pre-mutagen base that results from ROS-mediated DNA damage (Takane et al., 2002; Krol, 2004). Similarly, higher level of 8 -isoprostane concentration (an alternative approach to estimate lipid peroxidation) in the crevicular fluid of gingiva was detected in chronic periodontitis patients compared to those with gingivitis and healthy individuals (Pradeep et al., 2013). Serum reactive oxygen metabolite levels in periodontitis patients positively correlated to antibody levels with regard to bacteria such as Porphyromonas gingivalis, Prevotella intermedia, and Eikenella corrodens (Tamaki et al., 2014). Following scaling and root planning after systemic antioxidant lycopene administration, there was decrease in the oxidative stress and improvement in clinical parameters, which was maintained up to 4 months after discontinuation of antioxidant treatment (Ambati et al., 2017).

The pathogenesis of chronic inflammatory disease like oral lichen planus (OLP) is not well-understood (Tvarijonaviciute et al., 2017). Various studies showed that oxidative stress is involved in the pathogenesis of OLP. Significantly higher salivary ROS, lipid peroxidation, nitric oxide, and nitrite levels were found in OLP patients compared to the control subjects (Batu et al., 2016; Mehdipour et al., 2017; Tvarijonaviciute et al., 2017). The total antioxidant activity was significantly decreased in OLP patients with increased level of salivary malondialdehyde (MDA) compared to the healthy control group suggesting the possible role of the oxidants to orchestrate the disease via lipid peroxidationmediated pathway (Lopez-Jornet et al., 2014; Shiva and Arab, 2016).

Oxidative stress was also correlated with oral cancer, as increased lipid peroxidation and reduced antioxidants was reported in patients suffering from stage II, III, and IV oral cancer (Manoharan et al., 2005). In addition to these findings, nitric oxide-mediated DNA damage was reported in patients with oral leukoplakia. Samples of oral epithelium taken from these patients recorded high levels of 8-nitroguanine and 8-oxoG (Ma et al., 2006).

\section{OXIDATIVE STRESS MEDIATE CELLULAR DAMAGE}

The deleterious effects of ROS in the event of oxidative stress are through lipid peroxidation and irreversible protein modification that leads to cellular apoptosis or programmed cell death (Ferrari, 2000). Numerous pathways mediate oxidative cellular damage and these include as caspase pathway, PERK/NRF2 pathway, NADPH oxidase 4 pathway and JNK/mitogen-activated protein (MAP) kinase pathway. 


\section{PATHWAYS THAT MEDIATE OXIDATIVE CELLULAR DAMAGE}

\section{Caspase Pathway}

Caspases are a family of cysteine protease enzymes that carry out programmed cell death and inflammation. During apoptosis, caspases are activated to ensure that programmed cell death occurs with less damage to nearby tissues and also to ensure the degradation of components of the cell in a well-controlled manner (Rathore et al., 2015). Functionally, the caspases are classified into two major groups in apoptosis: Initiator caspases such as caspase- 8 and -9 , activate downstream caspases known as the executioner. These include caspase- $3,-6$, and -7 which are responsible for the breakdown of the cellular proteins (Creagh and Martin, 2001). In chronic periodontitis, caspase- 3 concentration was significantly increased in gingival crevicular fluid and serum, and significantly correlated to the probing depth, gingival index, and clinical attachment level, thereby indicating apoptosis plays an important role in the destruction of periodontium tissues in chronic periodontitis (Pradeep et al., 2016).

There are two major caspase-associated apoptotic pathways related to oxidative damage (1) mitochondrial mediated pathways, and (2) the death receptor mediated pathway. In cells, caspases exist as zymogens (pro-caspases) which are activated only in the presence of appropriate stimulus such as the insult of oxidative stress (Slee et al., 1999). During activation, the caspases undergo proteolytic cleaving to dimerize into an active enzyme (Alnemri et al., 1996). In the mitochondria-mediated apoptotic pathway, hydrogen peroxide $\left(\mathrm{H}_{2} \mathrm{O}_{2}\right)$ releases cytochrome $\mathrm{C}$ which binds to the apoptotic protease activating-factor 1 (Apaf-1) to initiate caspase-9 activation (Madesh and Hajnoczky, 2001; Andoh et al., 2002). ROS-mediated oxidative modification of caspase- 9 at $\mathrm{C} 403$ residue promotes the interaction of caspase-9 with Apaf-1 via disulfide bonding that results in the apoptosome formation which leads to activation of caspase- 9 (Zuo et al., 2009). The executioner, caspase-3 is speculated to be the converging point in both mitochondria-dependent and independent pathways in oxidative stress-driven apoptosis (Ueda et al., 2002; Kanthasamy et al., 2003). $\mathrm{H}_{2} \mathrm{O}_{2}$ activation of caspase3 lead to activation of PKC delta and this contributes to the nuclear DNA breakdown and apoptotic cell death (Carvour et al., 2008).

In death receptor-mediated apoptotic pathway, caspase- 8 channels apoptosis following oxidative stress (Baumgartner et al., 2007). Death receptors (also known as death-domain receptors) can promote the cleavage of pro-caspase- 8 with appropriate stimulation (Boldin et al., 1996). Then, caspase- 8 activates downstream executioner caspases (caspase-3; Jiang and Wang, 2004) or cleaves a pro-apoptotic protein known as Bid, which once activated translocates to the mitochondria and causes the release of cytochrome $\mathrm{C}$, followed by fragmentation of DNA and apoptosis ( $\mathrm{Li}$ et al., 1998). Interestingly, numerous studies reported crosstalk between caspase- 8 and caspase-9 (Figure 1; Basu et al., 2006; Mareninova et al., 2006). Using pancreatic acinar cells, Baumgartner et al. (2007) showed reported partial inhibition of caspase- 8 activation by caspase- 9 and vice versa during $\mathrm{H}_{2} \mathrm{O}_{2}$-mediated apoptosis. The same study also reported the involvement of lysosomal proteins such as cathedpsin D and $\mathrm{E}$ (aspartyl proteases from lysosomes) in activation of caspase- 8 .

\section{NADPH Oxidase 4 (NOX4) Pathway}

NADPH oxidases (NOX) are enzymes that are known to catalyze the electron transfer from NADPH to molecular oxygen, to generate ROS as a microcode in immune response (DeLeo and Quinn, 1996). NOX protein family consists of NOX1, -2, -3, and -4 (Sahoo et al., 2016). The NOX4 isoform is expressed everywhere in the body, including heart, neuron, kidney, liver, and endothelial cells (Byrne et al., 2003; Vallet et al., 2005; Ray et al., 2011; Babelova et al., 2012; Crosas-Molist et al., 2014). NOX4 predominantly generates $\mathrm{H}_{2} \mathrm{O}_{2}$ in mitochondria where it is usually localized (Ago et al., 2008; Nisimoto et al., 2014; Sanders et al., 2015).

Recent research highlighted the mechanistic effects of NOX4 in oxidative stress (Vendrov et al., 2015; Theccanat et al., 2016). Unlike other isoforms of NOX, the NOX4 do not require cytosolic regulatory subunits in order to be activated. Instead, the enzyme is regulated by transcription factors which include E2F (Zhang et al., 2008), AP-1/Smad3 complex (Bai et al., 2014), retinoblastoma protein kinase (by regulating the activity of $\mathrm{E} 2 \mathrm{~F}$ ), G-protein coupled receptor kinase 2 (Theccanat et al., 2016), and also via epigenetic regulation through increased association of histone H4K16 (Sanders et al., 2015). Enhanced NOX4 expression/activity and mitochondrial localization positively correlates to ROS production in mitochondria (Vendrov et al., 2015). Increased mitochondrial ROS leads to mitochondrial DNA damage, oxidation of mitochondrial proteins, and eventually apoptotic cell death (Madamanchi and Runge, 2013). This overproduced ROS is also likely to enter cytoplasm and activate numerous pro-apoptotic proteins such as caspase-9 and -3 (Tariq et al., 2013), caspase-1 (Moon et al., 2016). Excess ROS also causes a pro-inflammatory shift in the gene expression through nuclear factor-kappa- $\beta$ activation (NF- $\beta$; Ungvari et al., 2007). Significant increased NOX4 levels was observed following inflammatory or hypoxic stimulation in periodontal ligament cells, which was accompanied by up-regulation of ROS and catalase levels (Figure 2; Golz et al., 2014). However, prolonged exposure to both stimuli leads to a decreased in catalase level suggesting the collapse of the antioxidative mechanism favoring oxidative stress and inflammatory response as observed in periodontitis (Golz et al., 2014).

\section{NRF2-Antioxidant Response Element Signaling Pathway}

The nuclear factor erythroid 2 (NFE2)-related factor (NRF2), a basic leucine zipper (bZIP) protein from the cap " $n$ " collar (CNC) subfamily, protects against oxidative stress. NFE2 regulate the expression of antioxidant and detoxification proteins (Gold et al., 2012). NRF2 plays an important role in numerous diseases such as rheumatoid arthritis, atherosclerosis, oral cancer, and chronic periodontitis (Kim et al., 2010; Huang et al., 2013; Sima et al., 2016). NRF2 plays a role as a positive regulator of human Antioxidant Response Elements (AREs; Venugopal and Jaiswal, 1996). NRF2 was reported to regulate the expression 


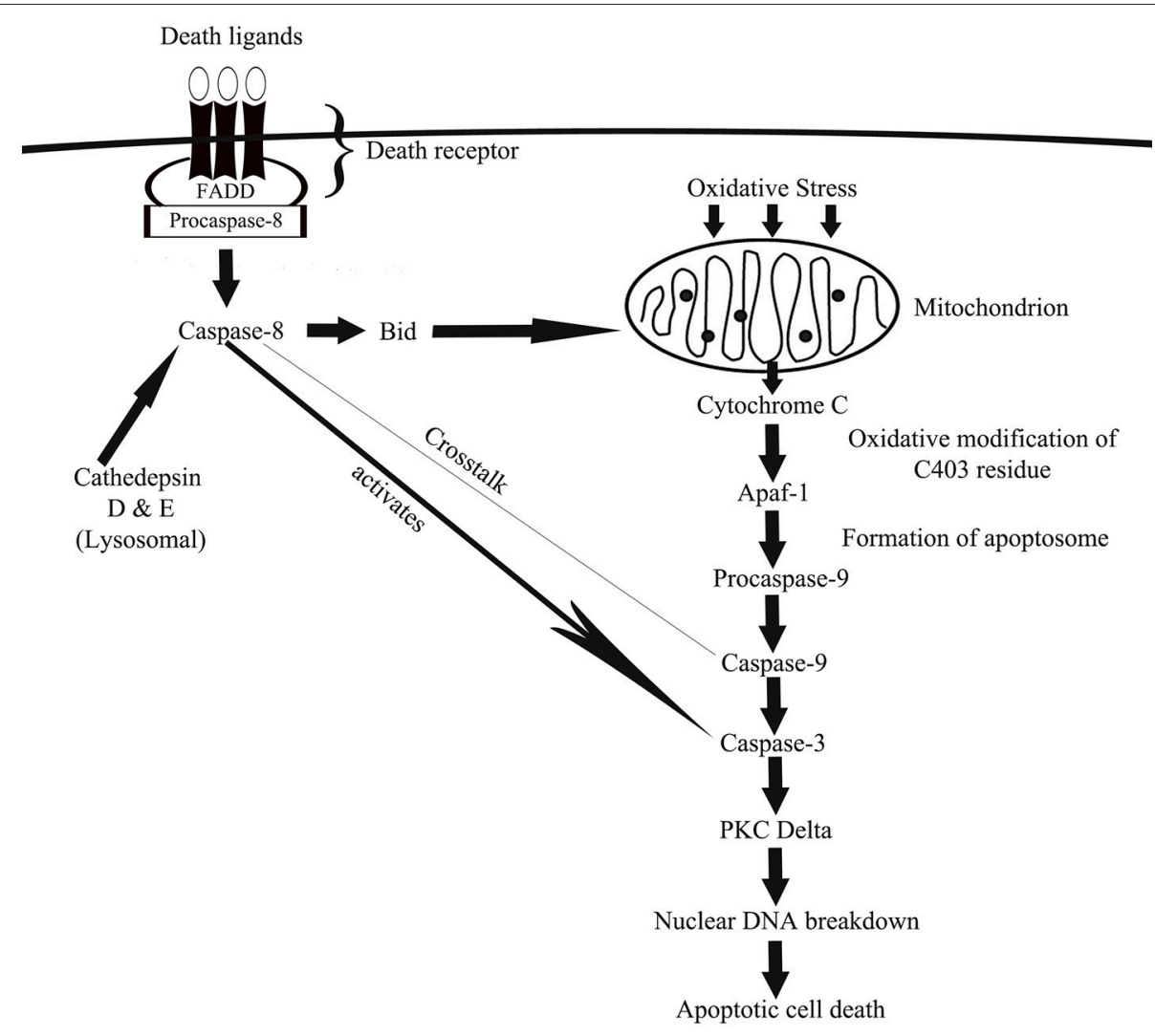

FIGURE 1 | A schematic depiction of how caspase-associated pathways leads to oxidative damage via mitochondrial- and death receptor-mediated cellular apoptosis. In mitochondrial-mediated apoptosis, generation of ROS causes the release of cytochrome $\mathrm{C}$ from mitochondria, which via a cascade of cellular actions activates caspase- 9 and then caspase- 3 that eventually channels cell death. In death receptor-mediated apoptosis, oxidative stress-driven death ligands activates caspase-8, which then activates a pro-apoptotic protein known as Bid, which once activated travels to mitochondria to facilitate mitochondria-mediated apoptotic pathway. Death receptor-activated caspase-8 also activates caspase-3 to induce cell death.

of numerous antioxidant enzymes, which include glutathione peroxidase, glutathione S-transferase, catalase, and superoxide dismutase (Niture et al., 2014).

The NRF2 activation was reported to involve a protein known as Kelch-like erythroid cell-derived protein with CNC homology-associated protein 1 (Keap 1) by Itoh et al. (1999). The same study reported that under basal condition, Keap 1 anchored to cytoplasm act as a suppressor of NRF2 by physically binding to NRF2 and prevent the translocation of NRF2 to the nucleus to activate ARE-containing gene promotor regions (Itoh et al., 1999). Under this condition, NRF2 is rapidly degraded by proteasomes (Kobayashi et al., 2004) through polyubiquitination via Keap1/Cul3 ubiquitin ligase (Wakabayashi et al., 2003). Keap1/NRF2 complex “senses" the oxidative stress directly via reactive cysteine residues in Keap1 (Dinkova-Kostova et al., 2004) and NRF2 (Huang et al., 2002). NRF2 is activated by protein kinase C, MAP kinase and phosphatidylinositol-3 kinase (Yu et al., 1999; Kang et al., 2002; Numazawa et al., 2003). Following the "oxidant sensing," NRF2 is phosphorylated at serine40 to be released from Keap1 (Huang et al., 2002) and translocates to the nucleus where there is formation of a heterodimer with Maf and binds to AREs of numerous antioxidant gene promoter regions to begin their transcription (Figure 3; Itoh et al., 1997).

The critical role of NRF2 in protection against oxidative stress was shown through myriad studies (Chan et al., 2001; Talalay et al., 2003; Motohashi and Yamamoto, 2004). A recent study reported significant down-regulation of NRF2 pathway in patients with severe chronic periodontitis (Sima et al., 2016). NRF2 over-expression significantly improved anti-oxidative levels, increased cell proliferation, and inhibited periodontal ligament stem cell apoptosis (Liu et al., 2017).

\section{Role of Different Inflammatory Markers}

Inflammation and oxidative stress were found to be associated with numerous chronic diseases such as diabetes, cardiovascular disease (CVD), hypertension, alcoholic liver diseases, neurodegenerative diseases, cancer, and aging (Biswas and de Faria, 2007; Cachofeiro et al., 2008; Ambade and Mandrekar, 2012; Tucker et al., 2015). The accepted hypothesis is that inflammation can trigger oxidative stress and the oxidation also can induce inflammation. 


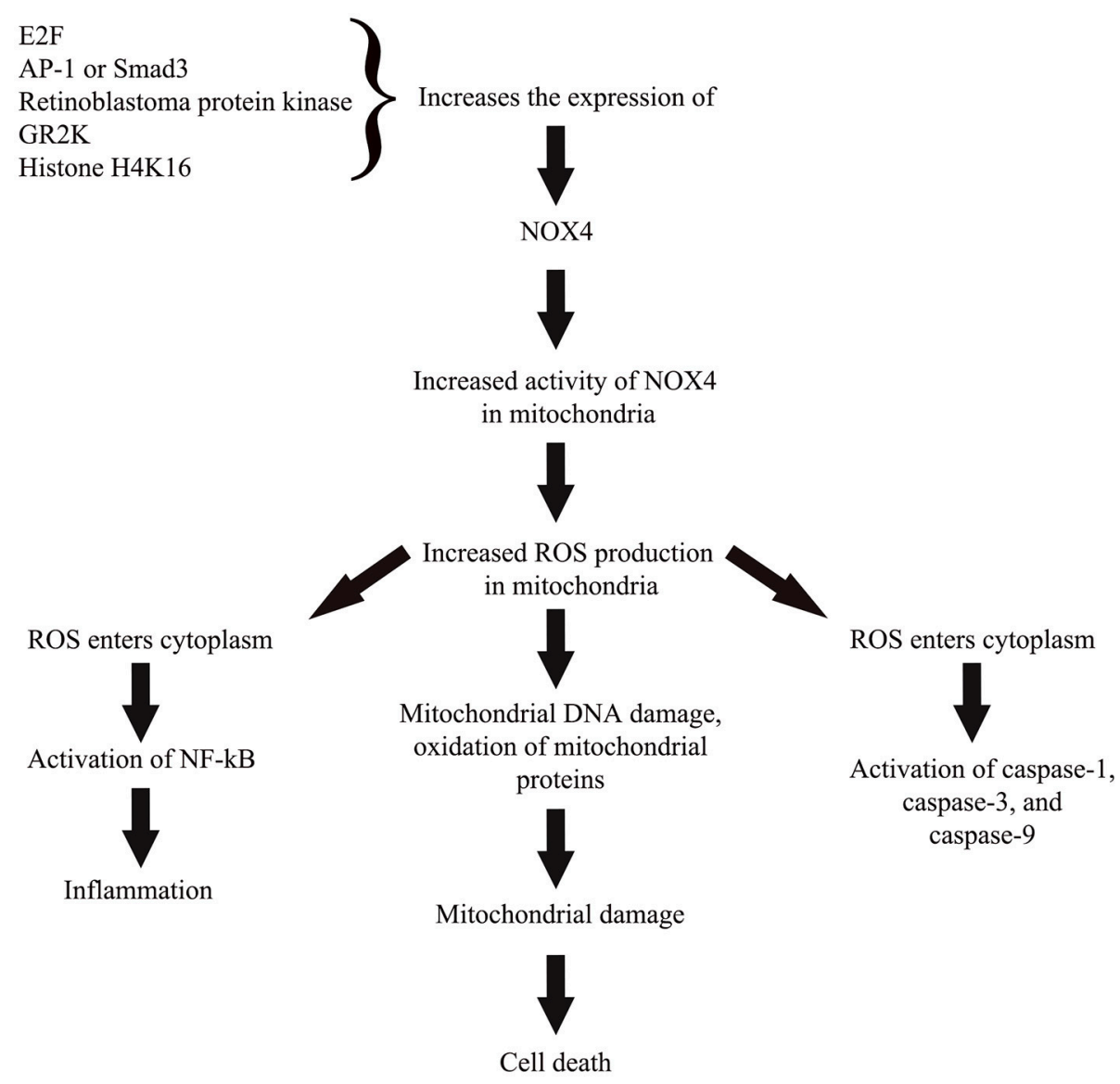

FIGURE 2 | A simplified representation on the role of NOX4 in cellular pathway toward ROS-induced oxidative stress. Activity of NOX4 is regulated through regulation of the enzyme's expression by various transcription factors, protein kinase, cellular receptor, and epigenetic regulator. Enhanced NOX4 expression or activity in mitochondria leads to increased ROS production that subsequently causes mitochondrial damage and cell death. Excess ROS also likely to travel toward cytoplasm and activate numerous pro-apoptotic proteins and also activate nuclear factor kappa beta to trigger a pro-inflammatory state of the cell.

Inflammation is the protective response of our biological system toward harmful exogenous and endogenous stimuli (Ferrero-Miliani et al., 2007). Inflammation is also an inherent immune response employed to safeguard our health. However, unregulated or exaggerated prolonged inflammation can cause tissue damage and chronic diseases. During the onset of inflammation, transcription factors such as activating protein-1 (AP-1) and NF- $\kappa \beta$ induce pro-inflammatory gene expressions, which increases production of ROS while inducing oxidative stress (Tabas and Glass, 2013). Certain ROS such as $\mathrm{H}_{2} \mathrm{O}_{2}$ can enhance the pro-inflammatory gene expression (Flohe et al., 1997) through activation of numerous cellular pathways. Oxidative stress activates NOD-like receptor protein 3 (NRLP3) inflammasome (Shimada et al., 2012) which are responsible for maturation of pro-inflammatory proteins such as interleukin (IL)-18 and IL-1 $\beta$ (Schroder and Tschopp, 2010). The expression of pro-IL-1 $\beta$ was upregulated in human oral squamous cell carcinoma tumors and it increased the proliferation of dysplasia oral cells, stimulated oncogenic cytokines, and promoted the severity of oral squamous cell carcinoma (Lee et al., 2015).

\section{Role of Oxygen Species Signal Assembly of the NLRP3 Inflammasome}

The inflammasome is a part of the innate immune system and it responds to microbes or cellular stress through regulation of caspase- 1 activation and induction of inflammation (Lamkanfi and Dixit, 2009). Among the numerous NLR inflammasome complexes such as NLRP1, -P2, -P3, -P6, -P12, and -C4 (Correa et al., 2012; Allen et al., 2013; Chen, 2014), the NLRP3 inflammasome influences the chronic inflammation and maturation of pro-inflammatory IL-1 $\beta$ and IL-18 (Davis et al., 2011). The expression of NLRP3 was significantly higher in patients with chronic periodontitis and generalized aggressive periodontitis, which were mainly distributed in inflammatory cells (Xue et al., 2015; Ran et al., 2017). P. gingivalis infection increased loss of alveolar bone, production of IL-1 $\beta$, IL-6, IL-18, gingival gene expression of pro-IL-18 and pro-IL-1 $\beta$, and activity of caspase- 1 in peritoneal macrophages of wildtype mice, unlike in NLRP3-deficient mice. This suggests that $P$. gingivalis activate innate immune cells through the NLRP3 inflammasome in periodontal disease (Yamaguchi et al., 


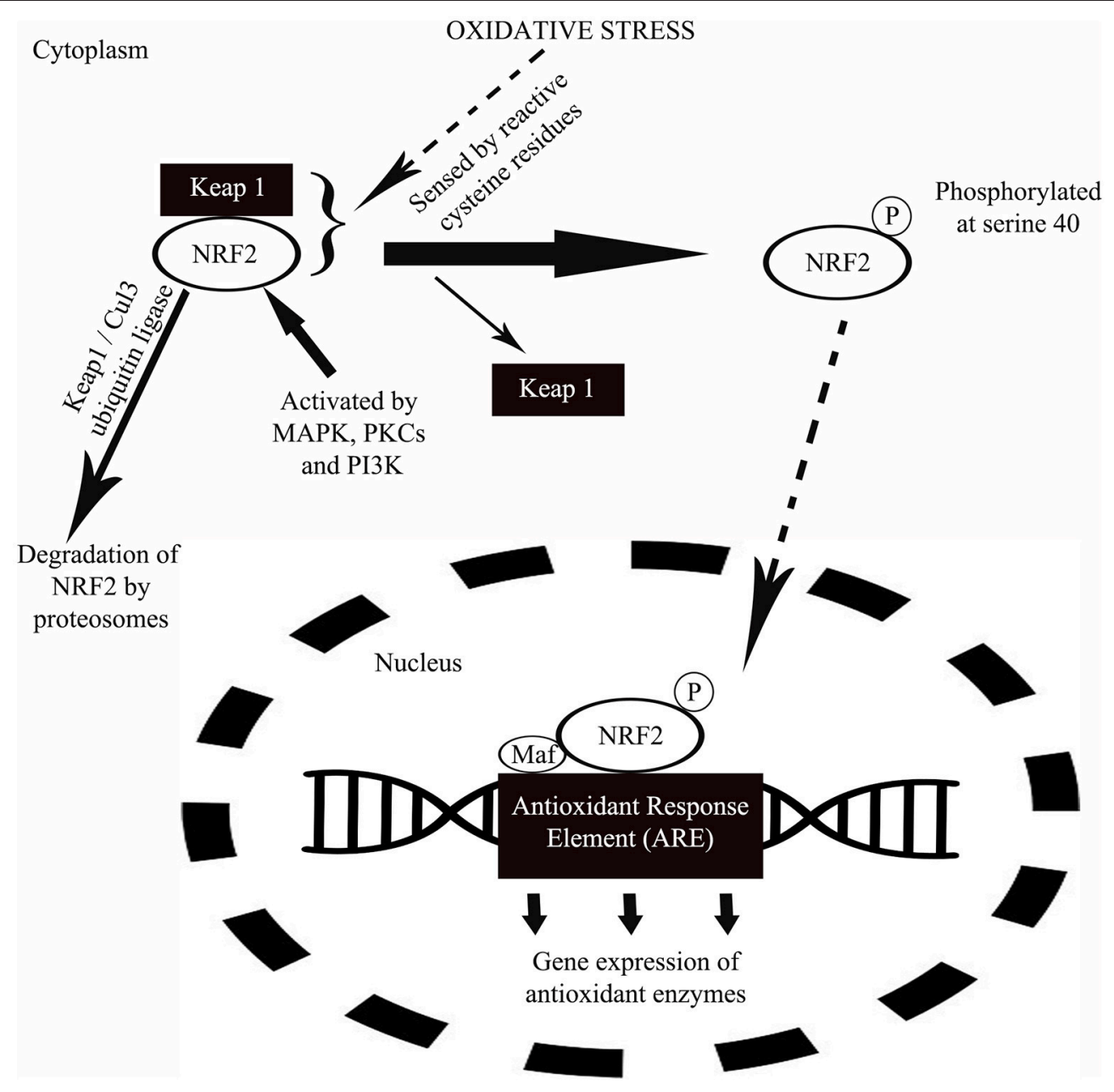

FIGURE 3 | A schematic diagram showing the mechanism of NRF2 in protection against oxidative stress. Under normal condition, a protein called Keap1 suppresses the activity of NRF2 by physically binding to NRF2 and at the same time anchored to cytoplasm. Following a period of inactivity, NRF2 is degraded by proteasomes. During oxidative stress, oxidants will be sensed by the Keap1/NRF2 complex via reactive cysteine residues in Keap1. Upon oxidant sensing, NRF2 undergoes phosphorylation at serine40 releasing Keap1 from the complex. This is followed by the translocation of NRF2 to nucleus where the protein forms a heterodimer with small transcription factor Maf and binds to antioxidant response enzyme (ARE) of numerous antioxidant gene promoter regions to initiate their transcription in response to oxidative stress.

2017). Similarly, Fusobacterium nucleatum infection involving the gingival epithelial cells, leads to NLRP3 inflammasomedependent secretion of IL-1 $\beta$ (Bui et al., 2016). Activation of NLRP3 causes the activation of caspase- 1 which is integral for the maturation of IL-18 and IL- $1 \beta$ into active cytokines and also the initiation of pryoptosis (Lamkanfi, 2011; Zhao et al., 2016).

Improper regulation of inflammasome could lead to the imbalance in between pro- and anti-inflammatory cytokines and result in inflammation and pryoptosis. NLRP3 inflammasome was reported to be activated by a host of molecules such as excess ROS, glucose, ATP, ceramides, sphingosine, crystals of cholesterol, uric acid, and oxidized LDL (Duewell et al., 2010; Jiang et al., 2012; Luheshi et al., 2012; Bandyopadhyay et al., 2013; Fukumoto et al., 2013). The exact underlying molecular mechanisms that regulate the assembly and activation of NLRP3 were not fully elucidated. However, recent studies reported the
ROS signaling to activate NLRP3 inflammasome (Fukumoto et al., 2013; Heid et al., 2013).

The cellular source of ROS in influencing the activation of NLRP3 inflammasome arises from the byproduct of mitochondrial oxidative phosphorylation, NOX, xanthine oxidase, cyclooxygenase, and lipooxygenase (Habu et al., 1990; Lacy et al., 1998; Andrew and Mayer, 1999; Paravicini and Touyz, 2008; Sorbara and Girardin, 2011; Heid et al., 2013). For mitochondrial-ROS dependent NRLP3 inflammasome activation, numerous molecules such as saturated fatty acid palmitate (Wen et al., 2011), liposome (Zhong et al., 2013), and mitochondrial cardiolipin (Iyer et al., 2013) were reported to be involved. NOX acts as a mediator in various molecules associated activation of NRLP3 complex. For an instance, excess of extracellular ATP binding to P2X7 receptors in mammals leads to rapid accumulation of ROS that eventually activate 
NRLP3 inflammasome (Riteau et al., 2012). The origin of ROS caused by excess ATP is reported to be NOX-derived (Cruz et al., 2007). Akin to ATP, alum, particulated metals and uric acid crystals were also shown to activate NLRP3 inflammasome via NOX-driven ROS generation (Martinon, 2010).

\section{Lipid Peroxidation as a Result of Infection}

Lipid peroxidation (LPO) is the oxidative deterioration of lipids caused by ROS. LPO is a chain reaction that mostly affects polyunsaturated fatty acids due to the presence of methylene bridges $\left(-\mathrm{CH}_{2}-\right)$ that possess reactive hydrogen atoms (Halliwell and Gutteridge, 1984). The chain reaction consists of three major steps including initiation, propagation and termination. For an in-depth information on the mechanism of LPO, we would suggest the readers to refer to review written by Repetto et al. (2012). The end-products of LPO are aldehyde, ethane, pentane, 2,3-transconjugated diens, isoprostains, and chlesteroloxides (Ustinova and Riabinin, 2003).

LPO has been implicated in numerous non-communicable diseases and aging-related disorders such as cataract, rheumatoid arthritis, atherosclerosis, and neurodegenerative diseases (Niki et al., 2005). In addition to these ailments, LPO was linked to infections such as influenza virus (Mileva et al., 2000; Kumar et al., 2003), acute and chronic fascioliasis (Kaya et al., 2007) and Helicobacter pylori infection (Davi et al., 2005). In addition, LPO as shown by salivary MDA level, was significantly increased in patients suffering from chronic periodontitis, OLP, oral leukoplakia, and oral squamous cell carcinoma (Baltacioglu et al., 2014; Malik et al., 2014; Metgud and Bajaj, 2014; Shirzad et al., 2014; Trivedi et al., 2015).

\section{Role of Polyphenols}

Polyphenols are naturally occurring compounds that are found in vegetables, fruits, beverages, herbs and spices. Examples of polyphenols include isoflavones, flavanols, flavones, phenolic acids, resveratrol, tannins, curcumin, anthovyanidins, and lignans (Tanigawa et al., 2007). In plants, polyphenols provide front line of protection from pathogens and ultraviolet light (Pandey and Rizvi, 2009).

Recent advances in research focusing on the antiinflammatory and antioxidant effects of the polyphenols have shed light on the mechanisms of the phenolic compounds in scavenging free radicals, regulation of cytokine activities, and the maintenance of antioxidant enzyme system. Phenolic compounds scavenge free radicals through donation of an electron or hydrogen atom to various reactive oxygen, chlorine and nitrogen species (Tsao and Li, 2012). Phenolic compounds also directly inhibit $\mathrm{Fe}^{3+}$ reduction and thus generate reactive $\mathrm{OH}$. (Perron and Brumaghim, 2009). These free radical scavenging and metal chelating effects of phenolic compounds interrupts the propagation stage of the LPO. Dietary phenolic compounds are able to restore inherent antioxidant enzymatic activities such as the superoxide dismutase, glutathione peroxidase, catalase, and glutathione reductase. Phenolic compounds control the expression of these enzymes through regulation of transcription factor NRF2 activities which in turn influences the ARE-mediated expression of the mentioned enzymes (Kohle and Bock, 2006). Flavanols, isoflavones, and flavones were reported to regulate the transcriptional activities of NRF2 (Zhang et al., 2003; Kohle and Bock, 2006).

In addition to antioxidant effects, dietary phenolic compounds were also shown to possess protective effects on inflammation through modulation of NLRP3 inflammasome. Recently, Hori et al. (2013) showed that green propolis rich in cinnamic acids inhibited inflammasome mediated secretion of IL-1 $\beta$ and activation of caspase-1. In separate studies, flavonoids such as procyanidin B2 and apigenin inhibited inflammasome-mediated secretion of IL-1 $\beta$ in LPS-induced human macrophages (Zhang et al., 2014; Martinez-Micaelo et al., 2015). Dietary phenolic compounds also reduced inflammation by attenuating pro-inflammatory cytokine-induced activation of NF- $\kappa \beta$ by acting as AhR agonist regulator. By doing such, phenolic compounds modulate AhR-mediated signaling pathways that are involved in the activation of NF- $\kappa \beta$ (Kohle and Bock, 2006; Vogel et al., 2014).

\section{HOW ORAL INFECTIONS ARE LINKED TO OTHER DISEASES}

Oral health is an important aspect of overall well-being of an organism. Numerous systemic conditions and diseases have oral origins (Beck et al., 1996; Li et al., 2000). At oral cavity, saliva act as the first line of defense against free radicals (Amerongen and Veerman, 2002; Battino et al., 2002) through antioxidants such as catalase, superoxide dismutase, and glutathione peroxidase (Battino et al., 2002). In the event of an infection, increased generation of free radicals outnumber antioxidants to initiate oxidative stress.

\section{Periodontitis and Circulating Oxidants}

Geerts et al. (2002) assessed the level of endotoxins in blood (proinflammatory factors) following mastication in patients with periodontitis. Endotoxin level was significantly higher following mastication in patients with severe periodontitis, thereby suggesting the possible detrimental effect of the oral disease on systemic health (Geerts et al., 2002). Myriad of clinical and pre-clinical findings were reported periodontal inflammationgenerated ROS to diffuse into bloodstream, and gradually affecting other organs (Sobaniec and Sobaniec-Lotowska, 2000; Tomofuji et al., 2007; Baltacioglu et al., 2014). In addition to oxidants, the level of circulatory antioxidants were reported to be lower in periodontitis patients (Baltacioglu et al., 2006; Konopka et al., 2007).

Smoking is regarded as one of the most significant risk factors for the development of periodontitis. Smoking can also increase oxidative stress. Smoking may affect the alveola and tooth loss may be a feature. Smoking is perhaps the only modifiable cause which can check periodontitis.

\section{Cardiovascular Disease}

Numerous cross-sectional studies and systematic reviews highlighted oral diseases, particularly periodontitis which could be a risk factor for development of atherosclerotic CVD (Ahn et al., 2016; Bengtsson et al., 2016; Berlin-Broner et al., 
2016; Gomes et al., 2016; Hansen et al., 2016; Khatri et al., 2016; Zeng et al., 2016; Beukers et al., 2017; Natarajan and Midhun, 2017). A cross-sectional analytical study showed an association between periodontitis and dental parameters (gingival recession, pocket depth, clinical attachment level, and bleeding on probing) with the severity of coronary artery obstruction being measured by angiography (Ketabi et al., 2016). Similarly, periodontitis was associated with increased thickness of carotid intima-media and arterial stiffness, which are indicators of subclinical atherosclerosis and predicts CVD risk (Houcken et al., 2016; Wu et al., 2016). However, studies also showed lack of significant association between periodontal variables and obstruction of coronary vessels (Zanella et al., 2016). The risk of a myocardial infarction for the first time and peripheral arterial disease was significantly increased in patients with periodontitis (Ryden et al., 2016; Calapkorur et al., 2017). The link between periodontal disease and CVD with respect of detailed clinical findings in the patient was summarized in Table 1. The role of different microorganisms, involvement of ROS, different mechanisms involved, inflammatory markers, and the development of CVD was also represented in Figure 4 .
The main mechanisms linking oral diseases to CVD involve actions of oral bacteria on the blood vessels, and systemic inflammation (Kholy et al., 2015). Bacterial (T. denticola,

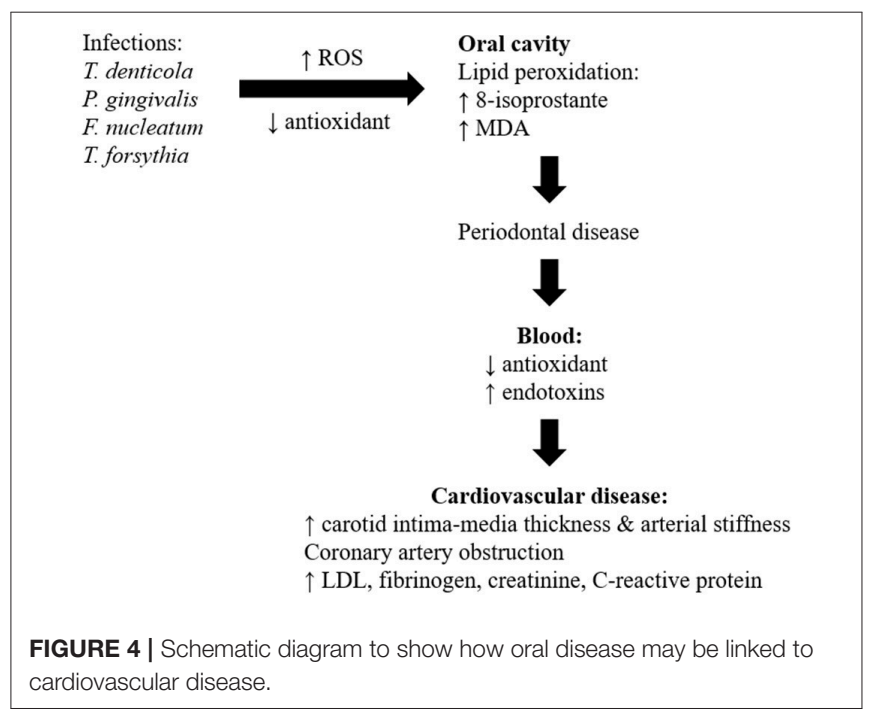

TABLE 1 | Association between periodontal disease and cardiovascular diseases.

\begin{tabular}{|c|c|c|c|}
\hline Participants & Sample size & Findings & References \\
\hline Adults with aged $>40$ years in Korea. & 1,343 & $\begin{array}{l}\text { Periodontitis was associated with subclinical } \\
\text { atherosclerosis and peripheral arterial disease. }\end{array}$ & Ahn et al., 2016 \\
\hline Adults with aged 60-96 years in Sweden. & 499 & $\begin{array}{l}\text { Significant association between periodontitis and } \\
\text { carotid calcification. }\end{array}$ & Bengtsson et al., 2016 \\
\hline Participants in the baltimore longitudinal study of aging. & 278 & $\begin{array}{l}\text { Periodontal disease, endodontic burden, number of } \\
\text { teeth and oral inflammatory burden were associated } \\
\text { with incident cardiovascular events. }\end{array}$ & Gomes et al., 2016 \\
\hline Periodontitis patients in Denmark & 100,694 & $\begin{array}{l}\text { Periodontitis patients were at higher risk of myocardial } \\
\text { infarction, ischemic stroke, cardiovascular death, major } \\
\text { adverse cardiovascular events, and all-cause mortality. }\end{array}$ & Hansen et al., 2016 \\
\hline Dental patients in University of Amsterdam. & 109 & $\begin{array}{l}\text { Periodontitis is associated with increased arterial } \\
\text { stiffness. }\end{array}$ & Houcken et al., 2016 \\
\hline Coronary artery obstruction patients in Isfahan, Iran. & 82 & $\begin{array}{l}\text { Positive correlation between variables gingival } \\
\text { recession, pocket depth, clinical attachment level, } \\
\text { decayed, missing, decayed-missing-filled, bleeding on } \\
\text { probing, and degree of coronary artery obstruction. }\end{array}$ & Ketabi et al., 2016 \\
\hline Adults with aged 35-65 years in Bhopal, India. & 40 & $\begin{array}{l}\text { Periodontitis patients was associated with higher carotid } \\
\text { intima-media thickness and diastolic blood pressure. }\end{array}$ & Khatri et al., 2016 \\
\hline $\begin{array}{l}\text { Adults with mean age } 46 \text { years, mean BMl } 21.1 \text { kg/m2 } \\
\text { in Bangladesh. }\end{array}$ & 917 & $\begin{array}{l}\text { Mean attachment loss was associated with increased } \\
\text { carotid intima-media thickness. }\end{array}$ & Wu et al., 2016 \\
\hline Patients that underwent coronary angiography. & 195 & $\begin{array}{l}\text { No significant associations were found between } \\
\text { periodontal variables and vessel obstruction. Tooth loss } \\
\text { was found to be a risk indicator for coronary heart } \\
\text { disease. }\end{array}$ & Zanella et al., 2016 \\
\hline Meta-analysis of 15 observational studies & 17,330 & $\begin{array}{l}\text { Presence of periodontal disease was associated with } \\
\text { carotid atherosclerosis. }\end{array}$ & Zeng et al., 2016 \\
\hline Dental patients aged > 35 years in Netherlands. & 60,174 & $\begin{array}{l}\text { Periodontitis showed significant association with } \\
\text { atherosclerosis. }\end{array}$ & Beukers et al., 2017 \\
\hline $\begin{array}{l}\text { Patients referred from the Department of Cardiovascular } \\
\text { Surgery to Department of Periodontology. }\end{array}$ & 60 & $\begin{array}{l}\text { Periodontitis raised the odds ratio for having peripheral } \\
\text { arterial disease. }\end{array}$ & Calapkorur et al., 2017 \\
\hline Adults with aged $20-40$ years in India. & 60 & $\begin{array}{l}\text { Severe generalized periodontitis was associated with } \\
\text { subclinical atherosclerosis }\end{array}$ & Natarajan and Midhun, 2017 \\
\hline
\end{tabular}


P. gingivalis, F. nucleatum, and T. forsythia) genomic DNA were detected in visceras such as aorta, heart, kidney, lung, and liver in mice induced with periodontitis suggesting that oral bacteria were able to gain entry into the blood stream from inflamed gingival thereby producing low-level transient bacteremia (Chukkapalli et al., 2017). Various periodontal bacteria were identified in atherosclerotic plaques and were deemed possible contributors to the disease. Different bacterial co-occurrences were detected in the plaques of subgingiva and plaque of atherosclerosis patients, including $T$. forsythia, $T$. denticol, $P$. gingivalis and $P$. nigrescens (Mahalakshmi et al., 2017). The bacteria in the atherosclerotic plaques created biofilms that stimulated the innate immune system reactant Toll-like receptor 2. This contributed to chronic inflammation and continued the immune system activation (Allen et al., 2016). Study also showed positive correlation between the periodontal bacteria levels and CVD risk associated mediators (low-density lipoprotein, fibrinogen, creatinine, and highly sensitive C-reactive proteins) levels in subjects with periodontitis and atherosclerosis (Bozoglan et al., 2017).

The local production and accumulation of inflammatory mediators in severe generalized periodontitis can cause systemic inflammation and endothelial dysfunction (Tonetti, 2009). $P$. gingivalis oral infection in mice, induced alterations in systemic cytokine production, i.e., up-regulation of matrix metalloproteinase 3, intercellular adhesion molecule 1 , insulinlike growth factor binding protein 2 , chemokine ( $\mathrm{C}-\mathrm{X}-\mathrm{C}$ motif) ligand 7 and the down-regulation of interleukin-17, L-selectin, and tumor necrosis factor- $\alpha$ (Miyauchi et al., 2012). Similarly in patients with coronary heart disease, periodontitis was associated with increased systemic inflammation (elevated IFN- $\gamma$, IL-10, and TNF- $\alpha$ levels; Kampits et al., 2016).

Recent studies indicated that periodontal treatment attenuated pro-artherosclerotic factors. Following periodontal treatment, white blood cells, low-density lipoprotein, platelet, fibrinogen, creatinine, and highly sensitive C-reactive proteins levels were significantly reduced and high-density lipoprotein levels significantly increased in patients with periodontitis and atherosclerosis, as well as in patients diagnosed with periodontitis alone (Bozoglan et al., 2017). Similarly, systemic markers of atherosclerosis: adrenomedullin and chemokine (C-C motif) ligand 28 levels changed significantly in the periodontitis and atherosclerotic patients, compared to the nonartherosclerotic periodontitis patients following non-surgical periodontal treatment. Decrease in serum neopterin induced by periodontal treatment contributed to the increased arterial elasticity in periodontitis patients (Ren et al., 2015). The results of these studies suggests that removal and reduction of these periodontal bacteria in subgingival plaque may be an important prophylactic measure to periodontitis and atherosclerosis (Mahalakshmi et al., 2017).

\section{Liver Diseases}

Using rat model of periodontitis (lipopolysaccharide/proteaseinduced), Tomofuji et al. (2008) reported oxidative DNA damage in the liver of experimental rats. Supporting the notion, another rat model of periodontitis, that is the ligature-induced model showed a decrease in the liver antioxidant, glutathione and increase in circulating level of hexanoyl-lysine suggesting a possible link between periodontitis-generated oxidants and liver damage (Tomofuji et al., 2008). In humans, limited literature has related periodontitis and liver diseases (Furuta et al., 2010; Han et al., 2016).

\section{Pancreatic Disease}

A recently published meta-analysis associated periodontitis with pancreatic cancer. The study estimated the relative risk for periodontitis and pancreatic cancer to be 1.74 (95\% Cl, 1.41-2.15) based on findings from three continents (Maisonneuve et al., 2017). Despite a large number of studies associating periodontitis and pancreatic, however, the underlying mechanism of the disease is poorly understood.

\section{Gastric Disorders}

H. pylori (bacteria implicated in gastritis and peptic ulcers) has been shown to be harbored by periodontal pockets in periodontitis patients (Soory, 2010). In parallel to this finding, periodontitis patients showed presence of $H$. pylori in subgingival biofilm (Riggio and Lennon, 1999; Gebara et al., 2004). Gastric carcinoma has been correlated with H.pylori infection-mediated ROS production, DNA damage along other endogenous and exogenous factors (Farinati et al., 2008). In a study investigating the effects of outer membrane vesicles of $H$. pylori in human gastric epithelial cells, oxidative stressassociated genomic damage with glutathione was noticed (Chitcholtan et al., 2008). In a separate study, H. pylori elicited mitochondrial damage in gastric epithelial cells, causing oxidative burst and mitochondrial-ROS mediated apoptosis (CalvinoFernandez et al., 2008).

\section{Alzheimer's Disease}

Studies have suggested significant association between periodontitis and Alzheimer's disease, which may be mediated through effects on systemic inflammation (Ide et al., 2016; Leira et al., 2017). The risk of developing dementia were higher for periodontitis patients aged 65 and older, compared to healthy individuals (Shin et al., 2016; Lee et al., 2017). Alzheimer's patients showed high serum IL-6 levels while periodontitis patients had high serum TNF- $\alpha$ levels (Cestari et al., 2016). The association between these cytokine levels in periodontitis and Alzheimer's patients suggests their implication in the overlapping mechanisms between periodontitis and Alzheimer's disease (Cestari et al., 2016). In addition, patients with severe periodontitis had higher blood $A \beta_{1-42}$ levels and higher $A \beta_{42 / 40}$ ratio (Gil-Montoya et al., 2017).

\section{SUMMARY AND PERSPECTIVE}

Oxidative stress causes damage to various organs in the human body. Proper understanding of oxidative stress and its pathways, free radicals and inflammatory markers related to oral diseases are important for effective treatment. Future drug targets may be planned according to the different pathways involved in inflammation and oxidative process. 


\section{AUTHOR CONTRIBUTIONS}

Conceptual framework and design: SD, PM. Searched references: JK and SLT. Drafted manuscript: SD, JK, and SLT. Critically revised the manuscript: SD, JK, SLT, PM.

\section{REFERENCES}

Ago, T., Liu, T., Zhai, P., Chen, W., Li, H., Molkentin, J. D., et al. (2008). A redoxdependent pathway for regulating class II HDACs and cardiac hypertrophy. Cell 133, 978-993. doi: 10.1016/j.cell.2008.04.041

Ahmadi-Motamayel, F., Goodarzi, M. T., Jamshidi, Z., and Kebriaei, R. (2017). Evaluation of salivary and serum antioxidant and oxidative stress statuses in patients with chronic periodontitis: a case-control study. Front. Physiol. 8:189. doi: 10.3389/fphys.2017.00189

Ahn, Y. B., Shin, M. S., Han, D. H., Sukhbaatar, M., Kim, M. S., Shin, H. S., et al. (2016). Periodontitis is associated with the risk of subclinical atherosclerosis and peripheral arterial disease in Korean adults. Atherosclerosis 251, 311-318. doi: 10.1016/j.atherosclerosis.2016.07.898

Akalin, F. A., Baltacioglu, E., Alver, A., and Karabulut, E. (2007). Lipid peroxidation levels and total oxidant status in serum, saliva and gingival crevicular fluid in patients with chronic periodontitis. J. Clin. Periodontol. 34, 558-565. doi: 10.1111/j.1600-051X.2007.01091.x

Allen, H. B., Boles, J., Morales, D., Ballal, S., and Joshi, S. G. (2016). Arteriosclerosis: the novel finding of biofilms and innate immune system activity within the plaques. J. Med. Surg. Pathol. 1:135. doi: 10.4172/jmsp.1000121

Allen, I. C., McElvania-TeKippe, E., Wilson, J. E., Lich, J. D., Arthur, J. C., Sullivan, J. T., et al. (2013). Characterization of NLRP12 during the in vivo host immune response to Klebsiella pneumoniae and Mycobacterium tuberculosis. PLoS ONE 8:e60842. doi: 10.1371/annotation/2190ebe1-452c-4966-9f74-9813378524d4

Alnemri, E. S., Livingston, D. J., Nicholson, D. W., Salvesen, G., Thornberry, N. A., Wong, W. W., et al. (1996). Human ICE/CED-3 protease nomenclature. Cell 87:171. doi: 10.1016/S0092-8674(00)81334-3

Ambade, A., and Mandrekar, P. (2012). Oxidative stress and inflammation: essential partners in alcoholic liver disease. Int. J. Hepatol. 2012:853175. doi: $10.1155 / 2012 / 853175$

Ambati, M., Rani, K. R., Reddy, P. V., Suryaprasanna, J., Dasari, R., and Gireddy, H. (2017). Evaluation of oxidative stress in chronic periodontitis patients following systemic antioxidant supplementation: a clinical and biochemical study. J. Nat. Sci. Biol. Med. 8, 99-103. doi: 10.4103/0976-9668.198366

Amerongen, A. V., and Veerman, E. C. (2002). Saliva-the defender of the oral cavity. Oral Dis. 8, 12-22. doi: 10.1034/j.1601-0825.2002.10816.x

Andoh, T., Chock, P. B., and Chiueh, C. C. (2002). The roles of thioredoxin in protection against oxidative stress-induced apoptosis in SH-SY5Y cells. J. Biol. Chem. 277, 9655-9660. doi: 10.1074/jbc.M110701200

Andrew, P. J., and Mayer, B. (1999). Enzymatic function of nitric oxide synthases. Cardiovasc. Res. 43, 521-531. doi: 10.1016/S0008-6363(99)00115-7

Babelova, A., Avaniadi, D., Jung, O., Fork, C., Beckmann, J., Kosowski, J., et al. (2012). Role of Nox4 in murine models of kidney disease. Free Radic. Biol. Med. 53, 842-853. doi: 10.1016/j.freeradbiomed.2012.06.027

Bai, G., Hock, T. D., Logsdon, N., Zhou, Y., and Thannickal, V. J. (2014). A far-upstream AP-1/Smad binding box regulates human NOX4 promoter activation by transforming growth factor- $\beta$. Gene 540, 62-67. doi: 10.1016/j.gene.2014.02.026

Baltacioglu, E., Akalin, F. A., Alver, A., Balaban, F., Unsal, M., and Karabulut, E. (2006). Total antioxidant capacity and superoxide dismutase activity levels in serum and gingival crevicular fluid in post-menopausal women with chronic periodontitis. J. Clin. Periodontol. 33, 385-392. doi: 10.1111/j.1600-051X.2006.00923.x

Baltacioglu, E., Yuva, P., Aydin, G., Alver, A., Kahraman, C., Karabulut, E., et al. (2014). Lipid peroxidation levels and total oxidant/antioxidant status in serum and saliva from patients with chronic and aggressive periodontitis. Oxidative stress index: a new biomarker for periodontal disease? J. Periodontol. 85, 1432-1441. doi: 10.1902/jop.2014.130654

\section{ACKNOWLEDGMENTS}

The authors acknowledge the help received from the Research Secretariat, Universiti Kebangsaan Malaysia Medical Centre.

Bandyopadhyay, S., Lane, T., Venugopal, R., Parthasarathy, P. T., Cho, Y. Galam, L., et al. (2013). MicroRNA-133a-1 regulates inflammasome activation through uncoupling protein-2. Biochem. Biophys. Res. Commun. 439, 407-412. doi: 10.1016/j.bbrc.2013.08.056

Basu, A., Castle, V. P., Bouziane, M., Bhalla, K., and Haldar, S. (2006). Crosstalk between extrinsic and intrinsic cell death pathways in pancreatic cancer: synergistic action of estrogen metabolite and ligands of death receptor family. Cancer Res. 66, 4309-4318. doi: 10.1158/0008-5472.CAN05-2657

Battino, M., Ferreiro, M. S., Gallardo, I., Newman, H. N., and Bullon, P. (2002). The antioxidant capacity of saliva. J. Clin. Periodontol. 29, 189-194. doi: 10.1034/j.1600-051X.2002.290301x.x

Batu, S., Ofluoglu, D., Ergun, S., Warnakulasuriya, S., Uslu, E., Guven, Y., et al. (2016). Evaluation of prolidase activity and oxidative stress in patients with oral lichen planus and oral lichenoid contact reactions. J. Oral Pathol. Med. 45, 281-288. doi: 10.1111/jop.12391

Baumgartner, H. K., Gerasimenko, J. V., Thorne, C., Ashurst, L. H., Barrow, S. L., Chvanov, M. A., et al. (2007). Caspase-8-mediated apoptosis induced by oxidative stress is independent of the intrinsic pathway and dependent on cathepsins. Am. J. Physiol. Gastrointest. Liver Physiol. 293, G296-G307. doi: 10.1152/ajpgi.00103.2007

Beck, J., Garcia, R., Heiss, G., Vokonas, P. S., and Offenbacher, S. (1996). Periodontal disease and cardiovascular disease. J. Periodontol. 67, 1123-1137. doi: 10.1902/jop.1996.67.10s.1123

Bengtsson, V. W., Persson, G. R., Berglund, J., and Renvert, S. (2016). A crosssectional study of the associations between periodontitis and carotid arterial calcifications in an elderly population. Acta Odontol. Scand. 74, 115-120. doi: 10.3109/00016357.2015.1050603

Berlin-Broner, Y., Febbraio, M., and Levin, L. (2016). Association between apical periodontitis and cardiovascular diseases: a systematic review of the literature. Int. Endod. J. 50, 847-859. doi: 10.1111/iej.12710

Beukers, N. G., van der Heijden, G. J., van Wijk, A. J., and Loos, B. G. (2017). Periodontitis is an independent risk indicator for atherosclerotic cardiovascular diseases among 60174 participants in a large dental school in the Netherlands. J. Epidemiol. Commun. Health 71, 37-42. doi: 10.1136/jech-2015-206745

Biswas, S. K., and de Faria, J. B. (2007). Which comes first: renal inflammation or oxidative stress in spontaneously hypertensive rats? Free Radic. Res. 41, 216-224. doi: 10.1080/10715760601059672

Boldin, M. P., Goncharov, T. M., Goltsev, Y. V., and Wallach, D. (1996). Involvement of $\mathrm{MACH}$, a novel MORT1/FADD-interacting protease, in Fas/APO-1- and TNF receptor-induced cell death. Cell 85, 803-815. doi: 10.1016/S0092-8674(00)81265-9

Bozoglan, A., Ertugrul, A. S., Taspinar, M., and Yuzbasioglu, B. (2017). Determining the relationship between atherosclerosis and periodontopathogenic microorganisms in chronic periodontitis patients. Acta Odontol. Scand. 75, 233-242. doi: 10.1080/00016357.2017.1280739

Bui, F. Q., Johnson, L., Roberts, J., Hung, S. C., Lee, J., Atanasova, K. R., et al. (2016). Fusobacterium nucleatum infection of gingival epithelial cells leads to NLRP3 inflammasome-dependent secretion of IL-1 $\beta$ and the danger signals ASC and HMGB1. Cell. Microbiol. 18, 970-981. doi: 10.1111/cmi.12560

Byrne, J. A., Grieve, D. J., Bendall, J. K., Li, J. M., Gove, C., Lambeth, J. D., et al. (2003). Contrasting roles of NADPH oxidase isoforms in pressure-overload versus angiotensin II-induced cardiac hypertrophy. Circ. Res. 93, 802-805. doi: 10.1161/01.RES.0000099504.30207.F5

Cachofeiro, V., Goicochea, M., de Vinuesa, S. G., Oubina, P., Lahera, V., and Luno, J. (2008). Oxidative stress and inflammation, a link between chronic kidney disease and cardiovascular disease. Kidney Int. Suppl. 111, S4-S9. doi: 10.1038/ki.2008.516 
Calapkorur, M. U., Alkan, B. A., Tasdemir, Z., Akcali, Y., and Saatci, E. (2017). Association of peripheral arterial disease with periodontal disease: analysis of inflammatory cytokines and an acute phase protein in gingival crevicular fluid and serum. J. Periodont. Res. 52, 532-539. doi: 10.1111/jre.12419

Calvino-Fernandez, M., Benito-Martinez, S., and Parra-Cid, T. (2008). Oxidative stress by Helicobacter pylori causes apoptosis through mitochondrial pathway in gastric epithelial cells. Apoptosis 13, 1267-1280. doi: 10.1007/s10495-008-0255-0

Canakci, C. F., Tatar, A., Canakci, V., Cicek, Y., Oztas, S., and Orbak, R. (2006). New evidence of premature oxidative DNA damage: mitochondrial DNA deletion in gingival tissue of patients with periodontitis. J. Periodontol. 77, 1894-1900. doi: 10.1902/jop.2006.060108

Carvour, M., Song, C., Kaul, S., Anantharam, V., Kanthasamy, A., and Kanthasamy, A. (2008). Chronic low-dose oxidative stress induces caspase-3dependent PKCd proteolytic activation and apoptosis in a cell culture model of dopaminergic neurodegeneration. Ann. N. Y. Acad. Sci. 1139, 197-205. doi: 10.1196/annals.1432.020

Cestari, J. A., Fabri, G. M., Kalil, J., Nitrini, R., Jacob-Filho, W., de Siqueira, J. T., et al. (2016). Oral infections and cytokine levels in patients with Alzheimer's disease and mild cognitive impairment compared with controls. J. Alzheimers Dis. 52, 1479-1485. doi: 10.3233/JAD-160212

Chan, K., Han, X. D., and Kan, Y. W. (2001). An important function of Nrf2 in combating oxidative stress: detoxification of acetaminophen. Proc. Natl. Acad. Sci. U.S.A. 98, 4611-4616. doi: 10.1073/pnas.081082098

Chen, G. Y. (2014). Role of Nlrp6 and Nlrp12 in the maintenance of intestinal homeostasis. Eur. J. Immunol. 44, 321-327. doi: 10.1002/eji.201344135

Chitcholtan, K., Hampton, M. B., and Keenan, J. I. (2008). Outer membrane vesicles enhance the carcinogenic potential of Helicobacter pylori. Carcinogenesis 29, 2400-2405. doi: 10.1093/carcin/bgn218

Chukkapalli, S. S., Easwaran, M., Rivera-Kweh, M. F., Velsko, I. M., Ambadapadi, S., Dai, J., et al. (2017). Sequential colonization of periodontal pathogens in induction of periodontal disease and atherosclerosis in LDLR ${ }^{\text {null }}$ mice. Pathog. Dis. 75:ftx003. doi: 10.1093/femspd/ftx003

Correa, R. G., Milutinovic, S., and Reed, J. C. (2012). Roles of NOD1 (NLRC1) and NOD2 (NLRC2) in innate immunity and inflammatory diseases. Biosci. Rep. 32, 597-608. doi: 10.1042/BSR20120055

Creagh, E. M., and Martin, S. J. (2001). Caspases: cellular demolition experts. Biochem. Soc. Trans. 29, 696-702. doi: 10.1042/bst0290696

Crosas-Molist, E., Bertran, E., Sancho, P., Lopez-Luque, J., Fernando, J., Sanchez, A., et al. (2014). The NADPH oxidase NOX4 inhibits hepatocyte proliferation and liver cancer progression. Free Radic. Biol. Med. 69, 338-347. doi: 10.1016/j.freeradbiomed.2014.01.040

Cruz, C. M., Rinna, A., Forman, H. J., Ventura, A. L., Persechini, P. M., and Ojcius, D. M. (2007). ATP activates a reactive oxygen species-dependent oxidative stress response and secretion of proinflammatory cytokines in macrophages. J. Biol. Chem. 282, 2871-2879. doi: 10.1074/jbc.M608083200

Davi, G., Neri, M., Falco, A., Festi, D., Taraborelli, T., Ciabattoni, G., et al. (2005). Helicobacter pylori infection causes persistent platelet activation in vivo through enhanced lipid peroxidation. Arterioscler. Thromb. Vasc. Biol. 25, 246-251. doi: 10.1161/01.ATV.0000147128.10278.99

Davis, B. K., Wen, H., and Ting, J. P. (2011). The inflammasome NLRs in immunity, inflammation, and associated diseases. Annu. Rev. Immunol. 29, 707-735. doi: 10.1146/annurev-immunol-031210-101405

Deas, E., Cremades, N., Angelova, P. R., Ludtmann, M. H., Yao, Z., Chen, S., et al. (2016). Alpha-synuclein oligomers interact with metal ions to induce oxidative stress and neuronal death in Parkinson's disease. Antioxid. Redox Signal. 24, 376-391. doi: 10.1089/ars.2015.6343

DeLeo, F. R., and Quinn, M. T. (1996). Assembly of the phagocyte NADPH oxidase: molecular interaction of oxidase proteins. J. Leukoc. Biol. 60, 677-691.

Dinkova-Kostova, A. T., Fahey, J. W., and Talalay, P. (2004). Chemical structures of inducers of nicotinamide quinone oxidoreductase 1 (NQO1). Methods Enzymol. 382, 423-448. doi: 10.1016/S0076-6879(04)82023-8

Duewell, P., Kono, H., Rayner, K. J., Sirois, C. M., Vladimer, G., Bauernfeind, F. G., et al. (2010). NLRP3 inflammasomes are required for atherogenesis and activated by cholesterol crystals. Nature 464, 1357-1361. doi: 10.1038/nature08938

El-Bahr, S. M. (2013). Biochemistry of free radicals and oxidative stress. Sci. Int. 1, 111-117. doi: $10.5567 /$ sciintl.2013.111.117
Fang, Y. Z., Yang, S., and Wu, G. (2002). Free radicals, antioxidants, and nutrition. Nutrition 18, 872-879. doi: 10.1016/S0899-9007(02)00916-4

Farinati, F., Cardin, R., Cassaro, M., Bortolami, M., Nitti, D., Tieppo, C., et al. (2008). Helicobacter pylori, inflammation, oxidative damage and gastric cancer: a morphological, biological and molecular pathway. Eur. J. Cancer Prev. 17, 195-200. doi: 10.1097/CEJ.0b013e3282f0bff5

Ferrari, C. K. B. (2000). Free radicals, lipid peroxidation and antioxidants in apoptosis: implications in cancer, cardiovascular and neurological diseases. Biologia 55, 581-590.

Ferrero-Miliani, L., Nielsen, O. H., Andersen, P. S., and Girardin, S. E. (2007). Chronic inflammation: importance of NOD2 and NALP3 in interleukin-1 $\beta$ generation. Clin. Exp. Immunol. 147, 227-235. doi: 10.1111/j.1365-2249.2006.03261.x

Flohe, L., Brigelius-Flohe, R., Saliou, C., Traber, M. G., and Packer, L. (1997). Redox regulation of NF-kappa B activation. Free Radic. Biol. Med. 22, 1115-1126. doi: 10.1016/S0891-5849(96)00501-1

Fridovich, I. (1999). Fundamental aspects of reactive oxygen species, or what's the matter with oxygen? Ann. N. Y. Acad. Sci. 893, 13-18.

Fukumoto, J., Fukumoto, I., Parthasarathy, P. T., Cox, R., Huynh, B., Ramanathan, G. K., et al. (2013). NLRP3 deletion protects from hyperoxiainduced acute lung injury. Am. J. Physiol. Cell Physiol. 305, C182-189. doi: 10.1152/ajpcell.00086.2013

Furuta, M., Ekuni, D., Yamamoto, T., Irie, K., Koyama, R., Sanbe, T., et al. (2010). Relationship between periodontitis and hepatic abnormalities in young adults. Acta Odontol. Scand. 68, 27-33. doi: 10.3109/00016350903 291913

Gebara, E. C., Pannuti, C., Faria, C. M., Chehter, L., Mayer, M. P., and Lima, L. A. (2004). Prevalence of Helicobacter pylori detected by polymerase chain reaction in the oral cavity of periodontitis patients. Oral Microbiol. Immunol. 19, 277-280. doi: 10.1111/j.1399-302X.2004.00153.x

Geerts, S. O., Nys, M., De, M. P., Charpentier, J., Albert, A., Legrand, V., et al. (2002). Systemic release of endotoxins induced by gentle mastication: association with periodontitis severity. J. Periodontol. 73, 73-78. doi: 10.1902/jop.2002.73.1.73

Gentric, G., Maillet, V., Paradis, V., Couton, D., L'Hermitte, A., Panasyuk, G., et al. (2015). Oxidative stress promotes pathologic polyploidization in nonalcoholic fatty liver disease. J. Clin. Invest. 125, 981-992. doi: 10.1172/JCI73957

Gilgun-Sherki, Y., Melamed, E., and Offen, D. (2001). Oxidative stress induced-neurodegenerative diseases: the need for antioxidants that penetrate the blood brain barrier. Neuropharmacology 40, 959-975. doi: 10.1016/S0028-3908(01)00019-3

Gil-Montoya, J. A., Barrios, R., Santana, S., Sanchez-Lara, I., Pardo, C. C., Fornieles-Rubio, F., et al. (2017). Association between periodontitis and amyloid- $\beta$ peptide in elderly people with and without cognitive impairment. I. Periodontol. doi: 10.1902/jop.2017.170071. [Epub ahead of print].

Gold, R., Kappos, L., Arnold, D. L., Bar-Or, A., Giovannoni, G., Selmaj, K., et al. (2012). Placebo-controlled phase 3 study of oral BG-12 for relapsing multiple sclerosis. N. Engl. J. Med. 367, 1098-1107. doi: 10.1056/NEJMoa 1114287

Golz, L., Memmert, S., Rath-Deschner, B., Jager, A., Appel, T., Baumgarten, G., et al. (2014). LPS from $P$. gingivalis and hypoxia increases oxidative stress in periodontal ligament fibroblasts and contributes to periodontitis. Mediators Inflamm. 2014:986264. doi: 10.1155/2014/986264

Gomes, M. S., Hugo, F. N., Hilgert, J. B., Sant'Ana Filho, M., Padilha, D. M., Simonsick, E. M., et al. (2016). Apical periodontitis and incident cardiovascular events in the baltimore longitudinal study of ageing. Int. Endod. J. 49, 334-342. doi: $10.1111 /$ iej.12468

Habu, H., Saito, N., Sato, Y., Takeshita, K., Sunagawa, M., and Endo, M. (1990). Results of surgery in patients with gastric cancer extending to the adjacent organs. Hepatogastroenterology 37, 417-420.

Halliwell, B., and Gutteridge, J. M. (1984). Oxygen toxicity, oxygen radicals, transition metals and disease. Biochem. J. 219, 1-14. doi: 10.1042/bj2190001

Han, P., Sun, D., and Yang, J. (2016). Interaction between periodontitis and liver diseases. Biomed. Rep. 5, 267-276. doi: 10.3892/br.2016.718

Hansen, G. M., Egeberg, A., Holmstrup, P., and Hansen, P. R. (2016) Relation of periodontitis to risk of cardiovascular and all-cause mortality (from a Danish nationwide cohort study). Am. J. Cardiol. 118, 489-493. doi: 10.1016/j.amjcard.2016.05.036 
Heid, M. E., Keyel, P. A., Kamga, C., Shiva, S., Watkins, S. C., and Salter, R. D. (2013). Mitochondrial reactive oxygen species induces NLRP3-dependent lysosomal damage and inflammasome activation. J. Immunol. 191, 5230-5238. doi: 10.4049/jimmunol.1301490

Hori, J. I., Zamboni, D. S., Carrao, D. B., Goldman, G. H., and Berretta, A. A. (2013). The Inhibition of Inflammasome by Brazilian Propolis (EPP-AF). Evid. Based Complement. Alternat. Med. 2013:418508. doi: 10.1155/2013/418508

Houcken, W., Teeuw, W. J., Bizzarro, S., Alvarez Rodriguez, E., Mulders, T. A., van den Born, B. J., et al. (2016). Arterial stiffness in periodontitis patients and controls. A case-control and pilot intervention study. J. Hum. Hypertens 30, 24-29. doi: 10.1038/jhh.2015.41

Huang, C. F., Zhang, L., Ma, S. R., Zhao, Z. L., Wang, W. M., He, K. F., et al. (2013). Clinical significance of Keap1 and Nrf2 in oral squamous cell carcinoma. PLoS ONE 8:e83479. doi: 10.1371/journal.pone.0083479

Huang, H. C., Nguyen, T., and Pickett, C. B. (2002). Phosphorylation of Nrf2 at Ser-40 by protein kinase $\mathrm{C}$ regulates antioxidant response element-mediated transcription. J. Biol. Chem. 277, 42769-42774. doi: 10.1074/jbc.M206911200

Ide, M., Harris, M., Stevens, A., Sussams, R., Hopkins, V., Culliford, D., et al. (2016). Periodontitis and cognitive decline in Alzheimer's disease. PLoS ONE 11:e0151081. doi: 10.1371/journal.pone.0151081

Itoh, K., Chiba, T., Takahashi, S., Ishii, T., Igarashi, K., Katoh, Y., et al. (1997). An Nrf2/small Maf heterodimer mediates the induction of phase II detoxifying enzyme genes through antioxidant response elements. Biochem. Biophys. Res. Commun. 236, 313-322. doi: 10.1006/bbrc.1997.6943

Itoh, K., Wakabayashi, N., Katoh, Y., Ishii, T., Igarashi, K., Engel, J. D., et al. (1999). Keap1 represses nuclear activation of antioxidant responsive elements by Nrf2 through binding to the amino-terminal Neh2 domain. Genes Dev. 13, 76-86. doi: $10.1101 /$ gad.13.1.76

Iyer, S. S., He, Q., Janczy, J. R., Elliott, E. I., Zhong, Z., Olivier, A. K., et al. (2013). Mitochondrial cardiolipin is required for Nlrp3 inflammasome activation. Immunity 39, 311-323. doi: 10.1016/j.immuni.2013.08.001

Jiang, X., and Wang, X. (2004). Cytochrome C-mediated apoptosis. Annu. Rev. Biochem. 73, 87-106. doi: 10.1146/annurev.biochem.73.011303.073706

Jiang, Y., Wang, M., Huang, K., Zhang, Z., Shao, N., Zhang, Y., et al. (2012). Oxidized low-density lipoprotein induces secretion of interleukin$1 \beta$ by macrophages via reactive oxygen species-dependent NLRP3 inflammasome activation. Biochem. Biophys. Res. Commun. 425, 121-126. doi: 10.1016/j.bbrc.2012.07.011

Jin, L. J., Lamster, I. B., Greenspan, J. S., Pitts, N. B., Scully, C., and Warnakulasuriya, S. (2016). Global burden of oral diseases: emerging concepts, management and interplay with systemic health. Oral Dis. 22, 609-619. doi: 10.1111/odi.12428

Joshi, S., Kumar, S., Ponnusamy, M. P., and Batra, S. K. (2016). Hypoxiainduced oxidative stress promotes MUC4 degradation via autophagy to enhance pancreatic cancer cells survival. Oncogene 35, 5882-5892. doi: 10.1038/onc.2016.119

Kampits, C., Montenegro, M. M., Ribeiro, I. W., Furtado, M. V., Polanczyk, C. A., Rosing, C. K., et al. (2016). Periodontal disease and inflammatory blood cytokines in patients with stable coronary artery disease. J. Appl. Oral Sci. 24, 352-358. doi: 10.1590/1678-775720160082

Kang, K. W., Lee, S. J., Park, J. W., and Kim, S. G. (2002). Phosphatidylinositol 3kinase regulates nuclear translocation of NF-E2-related factor 2 through actin rearrangement in response to oxidative stress. Mol. Pharmacol. 62, 1001-1010. doi: $10.1124 / \mathrm{mol} .62 .5 .1001$

Kanthasamy, A. G., Kitazawa, M., Kanthasamy, A., and Anantharam, V. (2003). Role of proteolytic activation of protein kinase C $\delta$ in oxidative stress-induced apoptosis. Antioxid. Redox Signal. 5, 609-620. doi: 10.1089/152308603770310275

Kanzaki, H., Wada, S., Narimiya, T., Yamaguchi, Y., Katsumata, Y., Itohiya, K., et al. (2017). Pathways that regulate ROS scavenging enzymes, and their role in defense against tissue destruction in periodontitis. Front. Physiol. 8:351. doi: 10.3389/fphys.2017.00351

Kassebaum, N. J., Smith, A. G. C., Bernabe, E., Fleming, T. D., Reynolds, A. E., Vos, T., et al. (2017). Global, regional, and national prevalence, incidence, and disability-adjusted life years for oral conditions for 195 countries, 1990-2015: a systematic analysis for the global burden of diseases, injuries, and risk factors. J. Dent. Res. 96, 380-387. doi: 10.1177/0022034517693566
Kataoka, K., Ekuni, D., Tomofuji, T., Irie, K., Kunitomo, M., Uchida, Y., et al. (2016). Visualization of oxidative stress induced by experimental periodontitis in Keap1-dependent oxidative stress detector-luciferase mice. Int. J. Mol. Sci. 17:1907. doi: 10.3390/ijms17111907

Kaya, S., Sutcu, R., Cetin, E. S., Aridogan, B. C., Delibas, N., and Demirci, M. (2007). Lipid peroxidation level and antioxidant enzyme activities in the blood of patients with acute and chronic fascioliasis. Int. J. Infect. Dis. 11, 251-255. doi: 10.1016/j.ijid.2006.05.003

Ketabi, M., Meybodi, F. R., and Asgari, M. R. (2016). The association between periodontal disease parameters and severity of atherosclerosis. Dent. Res. J. 13, 250-255. doi: 10.4103/1735-3327.182185

Khatri, R., Deshmukh, J., Shrivastava, R., Gupta, S., Kawadkar, A., and Vinaya Kumar, K. (2016). Is periodontitis an independent risk factor for subclinical atherosclerosis? Singapore Dent. J. 37, 9-13. doi: 10.1016/j.sdj.2016. 10.004

Kholy, K. E., Genco, R. J., and Van Dyke, T. E. (2015). Oral infections and cardiovascular disease. Trends Endocrinol. Metab. 26, 315-321. doi: 10.1016/j.tem.2015.03.001

Kim, J., Cha, Y. N., and Surh, Y. J. (2010). A protective role of nuclear factorerythroid 2-related factor-2 (Nrf2) in inflammatory disorders. Mutat. Res. 690, 12-23. doi: 10.1016/j.mrfmmm.2009.09.007

Kobayashi, A., Kang, M. I., Okawa, H., Ohtsuji, M., Zenke, Y., Chiba, T., et al. (2004). Oxidative stress sensor Keap1 functions as an adaptor for Cul3-based E3 ligase to regulate proteasomal degradation of Nrf2. Mol. Cell. Biol. 24, 7130-7139. doi: 10.1128/MCB.24.16.7130-7139.2004

Kohle, C., and Bock, K. W. (2006). Activation of coupled Ah receptor and Nrf2 gene batteries by dietary phytochemicals in relation to chemoprevention. Biochem. Pharmacol. 72, 795-805. doi: 10.1016/j.bcp.2006.04.017

Konopka, T., Krol, K., Kopec, W., and Gerber, H. (2007). Total antioxidant status and 8-hydroxy-2'-deoxyguanosine levels in gingival and peripheral blood of periodontitis patients. Arch. Immunol. Ther. Exp. 55, 417-422. doi: 10.1007/s00005-007-0047-1

Krol, K. (2004). Reactive oxygen species and antioxidant mechanisms in the pathogenesis of periodontitis. Ann. Acad. Med. Stetin. 50, 135-148.

Kumar, P., Sharma, S., Khanna, M., and Raj, H. G. (2003). Effect of Quercetin on lipid peroxidation and changes in lung morphology in experimental influenza virus infection. Int. J. Exp. Pathol. 84, 127-133. doi: 10.1046/j.1365-2613.2003.00344.x

Lacy, F., Gough, D. A., and Schmid-Schonbein, G. W. (1998). Role of xanthine oxidase in hydrogen peroxide production. Free Radic. Biol. Med. 25, 720-727. doi: 10.1016/S0891-5849(98)00154-3

Lamkanfi, M. (2011). Emerging inflammasome effector mechanisms. Nat. Rev. Immunol. 11, 213-220. doi: 10.1038/nri2936

Lamkanfi, M., and Dixit, V. M. (2009). Inflammasomes: guardians of cytosolic sanctity. Immunol. Rev. 227, 95-105. doi: 10.1111/j.1600-065X.2008.00730.x

Lee, C. H., Chang, J. S., Syu, S. H., Wong, T. S., Chan, J. Y., Tang, Y. C., et al. (2015). IL-1 $\beta$ promotes malignant transformation and tumor aggressiveness in oral cancer. J. Cell. Physiol. 230, 875-884. doi: 10.1002/jcp.24816

Lee, Y. T., Lee, H. C., Hu, C. J., Huang, L. K., Chao, S. P., Lin, C. P., et al. (2017). Periodontitis as a modifiable risk factor for dementia: a nationwide populationbased cohort study. J. Am. Geriatr. Soc. 65, 301-305. doi: 10.1111/jgs.14449

Leira, Y., Dominguez, C., Seoane, J., Seoane-Romero, J., Pias-Peleteiro, J. M., Takkouche, B., et al. (2017). Is periodontal disease associated with Alzheimer's disease? A systematic review with meta-analysis. Neuroepidemiology 48, 21-31. doi: $10.1159 / 000458411$

Li, H., Zhu, H., Xu, C. J., and Yuan, J. (1998). Cleavage of BID by caspase 8 mediates the mitochondrial damage in the Fas pathway of apoptosis. Cell 94, 491-501. doi: 10.1016/S0092-8674(00)81590-1

Li, X., Kolltveit, K. M., Tronstad, L., and Olsen, I. (2000). Systemic diseases caused by oral infection. Clin. Microbiol. Rev. 13, 547-558. doi: 10.1128/CMR.13.4.547-558.2000

Listl, S., Galloway, J., Mossey, P. A., and Marcenes, W. (2015). Global economic impact of dental diseases. J. Dent. Res. 94, 1355-1361. doi: 10.1177/0022034515602879

Liu, Y., Yang, H., Wen, Y., Li, B., Zhao, Y., Xing, J., et al. (2017). Nrf2 inhibits periodontal ligament stem cell apoptosis under excessive oxidative stress. Int. J. Mol. Sci. 18:1076. doi: 10.3390/ijms18051076 
Lopez-Jornet, P., Martinez-Canovas, A., and Pons-Fuster, A. (2014). Salivary biomarkers of oxidative stress and quality of life in patients with oral lichen planus. Geriatr. Gerontol. Int. 14, 654-659. doi: 10.1111/ ggi. 12153

Luheshi, N. M., Giles, J. A., Lopez-Castejon, G., and Brough, D. (2012). Sphingosine regulates the NLRP3-inflammasome and IL-1 $\beta$ release from macrophages. Eur. J. Immunol. 42, 716-725. doi: 10.1002/eji.201142079

Ma, N., Tagawa, T., Hiraku, Y., Murata, M., Ding, X., and Kawanishi, S. (2006). 8Nitroguanine formation in oral leukoplakia, a premalignant lesion. Nitric Oxide 14, 137-143. doi: 10.1016/j.niox.2005.09.012

Madamanchi, N. R., and Runge, M. S. (2013). Redox signaling in cardiovascular health and disease. Free Radic. Biol. Med. 61, 473-501. doi: 10.1016/j.freeradbiomed.2013.04.001

Madesh, M., and Hajnoczky, G. (2001). VDAC-dependent permeabilization of the outer mitochondrial membrane by superoxide induces rapid and massive cytochrome c release. J. Cell Biol. 155, 1003-1015. doi: 10.1083/jcb.200105057

Mahalakshmi, K., Krishnan, P., and Arumugam, S. B. (2017). "Association of periodontopathic anaerobic bacterial co-occurrence to atherosclerosis" - a cross-sectional study. Anaerobe 44, 66-72. doi: 10.1016/j.anaerobe.2017.02.003

Maisonneuve, P., Amar, S., and Lowenfels, A. B. (2017). Periodontal disease, edentulism, and pancreatic cancer: a meta-analysis. Ann. Oncol. 28, 985-995. doi: 10.1093/annonc/mdx019

Malik, U. U., Siddiqui, I. A., Hashim, Z., and Zarina, S. (2014). Measurement of serum paraoxonase activity and MDA concentrations in patients suffering with oral squamous cell carcinoma. Clin. Chim. Acta 430, 38-42. doi: 10.1016/j.cca.2013.12.033

Manoharan, S., Kolanjiappan, K., Suresh, K., and Panjamurthy, K. (2005). Lipid peroxidation \& antioxidants status in patients with oral squamous cell carcinoma. Indian J. Med. Res. 122, 529-534.

Mareninova, O. A., Sung, K. F., Hong, P., Lugea, A., Pandol, S. J., Gukovsky, I., et al. (2006). Cell death in pancreatitis: caspases protect from necrotizing pancreatitis. J. Biol. Chem. 281, 3370-3381. doi: 10.1074/jbc.M511276200

Martinez-Micaelo, N., Gonzalez-Abuin, N., Pinent, M., Ardevol, A., and Blay, M. (2015). Procyanidin B2 inhibits inflammasome-mediated IL-1 $\beta$ production in lipopolysaccharide-stimulated macrophages. Mol. Nutr. Food Res. 59, 262-269. doi: $10.1002 / \mathrm{mnfr} .201400370$

Martinon, F. (2010). Signaling by ROS drives inflammasome activation. Eur. J. Immunol. 40, 616-619. doi: 10.1002/eji.200940168

Matthews, J. B., Wright, H. J., Roberts, A., Ling-Mountford, N., Cooper, P. R., and Chapple, I. L. (2007). Neutrophil hyper-responsiveness in periodontitis. J. Dent. Res. 86, 718-722. doi: 10.1177/154405910708600806

McCord, J. M. (2000). The evolution of free radicals and oxidative stress. Am. J. Med. 108, 652-659. doi: 10.1016/S0002-9343(00)00412-5

Mehdipour, M., Taghavi Zenouz, A., Dastanpour, S., Bahramian, A., Gholizadeh, N., and Azari-Marhabi, S. (2017). Evaluation of serum malondialdehyde level in patients with oral lichen planus. Caspian J. Dent. Res. 6, 45-48.

Metgud, R., and Bajaj, S. (2014). Evaluation of salivary and serum lipid peroxidation, and glutathione in oral leukoplakia and oral squamous cell carcinoma. J. Oral Sci. 56, 135-142. doi: 10.2334/josnusd.56.135

Mileva, M., Tancheva, L., Bakalova, R., Galabov, A., Savov, V., and Ribarov, S. (2000). Effect of vitamin E on lipid peroxidation and liver monooxigenase activity in experimental influenza virus infection. Toxicol. Lett. 114, 39-45. doi: 10.1016/S0378-4274(99)00265-9

Miyauchi, S., Maekawa, T., Aoki, Y., Miyazawa, H., Tabeta, K., Nakajima, T., et al. (2012). Oral infection with Porphyromonas gingivalis and systemic cytokine profile in C57BL/6.KOR-ApoE ${ }^{\text {shl }}$ mice. J. Periodont. Res. 47, 402-408. doi: 10.1111/j.1600-0765.2011.01441.x

Moon, J. S., Nakahira, K., Chung, K. P., DeNicola, G. M., Koo, M. J., Pabon, M. A., et al. (2016). NOX4-dependent fatty acid oxidation promotes NLRP3 inflammasome activation in macrophages. Nat. Med. 22, 1002-1012. doi: $10.1038 / \mathrm{nm} .4153$

Mota, S. I., Costa, R. O., Ferreira, I. L., Santana, I., Caldeira, G. L., Padovano, C., et al. (2015). Oxidative stress involving changes in Nrf2 and ER stress in early stages of Alzheimer's disease. Biochim. Biophys. Acta 1852, 1428-1441. doi: 10.1016/j.bbadis.2015.03.015

Motohashi, H., and Yamamoto, M. (2004). Nrf2-Keap1 defines a physiologically important stress response mechanism. Trends Mol. Med. 10, 549-557. doi: 10.1016/j.molmed.2004.09.003
Natarajan, U. M., and Midhun, M. (2017). A study of association between severe periodontitis with subclinical atherosclerosis in young subjects. Int. J. Comtemporary Med. 5, 36-41. doi: 10.5958/2321-1032.2017.00008.0

Niki, E., Yoshida, Y., Saito, Y., and Noguchi, N. (2005). Lipid peroxidation: mechanisms, inhibition, and biological effects. Biochem. Biophys. Res. Commun. 338, 668-676. doi: 10.1016/j.bbrc.2005.08.072

Nisimoto, Y., Diebold, B. A., Cosentino-Gomes, D., and Lambeth, J. D. (2014). Nox4: a hydrogen peroxide-generating oxygen sensor. Biochemistry 53, 5111-5120. doi: 10.1021/bi500331y

Niture, S. K., Khatri, R., and Jaiswal, A. K. (2014). Regulation of Nrf2-an update. Free Radic. Biol. Med. 66, 36-44. doi: 10.1016/j.freeradbiomed.2013.02.008

Numazawa, S., Ishikawa, M., Yoshida, A., Tanaka, S., and Yoshida, T. (2003). Atypical protein kinase C mediates activation of NF-E2-related factor 2 in response to oxidative stress. Am. J. Physiol. Cell Physiol. 285, C334-C342. doi: 10.1152/ajpcell.00043.2003

Oh, B., Figtree, G., Costa, D., Eade, T., Hruby, G., Lim, S., et al. (2016). Oxidative stress in prostate cancer patients: a systematic review of case control studies. Prostate Int. 4, 71-87. doi: 10.1016/j.prnil.2016.05.002

Pandey, K. B., and Rizvi, S. I. (2009). Plant polyphenols as dietary antioxidants in human health and disease. Oxid. Med. Cell. Longev. 2, 270-278. doi: 10.4161 /oxim.2.5.9498

Paravicini, T. M., and Touyz, R. M. (2008). NADPH oxidases, reactive oxygen species, and hypertension: clinical implications and therapeutic possibilities. Diabetes Care 31(Suppl. 2), S170-S180. doi: 10.2337/dc08-s247

Perron, N. R., and Brumaghim, J. L. (2009). A review of the antioxidant mechanisms of polyphenol compounds related to iron binding. Cell Biochem. Biophys. 53, 75-100. doi: 10.1007/s12013-009-9043-x

Pisoschi, A. M., and Pop, A. (2015). The role of antioxidants in the chemistry of oxidative stress: a review. Eur. J. Med. Chem. 97, 55-74. doi: 10.1016/j.ejmech.2015.04.040

Pradeep, A. R., Rao, N. S., Bajaj, P., and Agarwal, E. (2013). 8-Isoprostane: a lipid peroxidation product in gingival crevicular fluid in healthy, gingivitis and chronic periodontitis subjects. Arch. Oral Biol. 58, 500-504. doi: 10.1016/j.archoralbio.2013.01.011

Pradeep, A. R., Suke, D. K., Prasad, M. V., Singh, S. P., Martande, S. S., Nagpal, K., et al. (2016). Expression of key executioner of apoptosis caspase3 in periodontal health and disease. J. Investig. Clin. Dent. 7, 174-179. doi: 10.1111/jicd.12134

Ran, S., Liu, B., Gu, S., Sun, Z., and Liang, J. (2017). Analysis of the expression of NLRP3 and AIM2 in periapical lesions with apical periodontitis and microbial analysis outside the apical segment of teeth. Arch. Oral Biol. 78, 39-47. doi: 10.1016/j.archoralbio.2017.02.006

Rathore, S., Datta, G., Kaur, I., Malhotra, P., and Mohmmed, A. (2015) Disruption of cellular homeostasis induces organelle stress and triggers apoptosis like cell-death pathways in malaria parasite. Cell Death Dis. 6:e1803. doi: $10.1038 /$ cddis.2015.142

Ray, R., Murdoch, C. E., Wang, M., Santos, C. X., Zhang, M., Alom-Ruiz, S., et al. (2011). Endothelial Nox4 NADPH oxidase enhances vasodilatation and reduces blood pressure in vivo. Arterioscler. Thromb. Vasc. Biol. 31, 1368-1376. doi: 10.1161/ATVBAHA.110.219238

Ren, J., Chen, Y. B., Zhang, Y. Y., Zhou, Q. B., Chen, S., Yang, J. Y., et al. (2015). Decreased circulating neopterin is associated with increased arterial elasticity: a beneficial role of periodontal treatment. Aust. Dent. J. 61, 76-83. doi: 10.1111 /adj.12303

Repetto, M., Semprine, J., and Boveris, A. (2012). "Lipid peroxidation: chemical mechanism, biological implications and analytical determination," in Biochemistry, Genetics and Molecular Biology, ed A. Catala (INTECH). doi: 10.5772/45943. Available online at: https://www.intechopen.com/books/ lipid-peroxidation/lipid-peroxidation-chemical-mechanism-biologicalimplications-and-analytical-determination

Riggio, M. P., and Lennon, A. (1999). Identification by PCR of Helicobacter pylori in subgingival plaque of adult periodontitis patients. J. Med. Microbiol. 48, 317-322. doi: 10.1099/00222615-48-3-317

Riteau, N., Baron, L., Villeret, B., Guillou, N., Savigny, F., Ryffel, B., et al. (2012). ATP release and purinergic signaling: a common pathway for particle-mediated inflammasome activation. Cell Death Dis. 3:e403. doi: 10.1038/cddis.2012.144

Ryden, L., Buhlin, K., Ekstrand, E., de Faire, U., Gustafsson, A., Holmer, J., et al. (2016). Periodontitis increases the risk of a first myocardial 
infarction: A report from the PAROKRANK study. Circulation 133, 576-583. doi: 10.1161/CIRCULATIONAHA.115.020324

Saed, G. M., Diamond, M. P., and Fletcher, N. M. (2017). Updates of the role of oxidative stress in the pathogenesis of ovarian cancer. Gynecol. Oncol. 145, 595-602. doi: 10.1016/j.ygyno.2017.02.033

Sahoo, S., Meijles, D. N., and Pagano, P. J. (2016). NADPH oxidases: key modulators in aging and age-related cardiovascular diseases? Clin. Sci. 130, 317-335. doi: 10.1042/CS20150087

Sanders, Y. Y., Liu, H., Liu, G., and Thannickal, V. J. (2015). Epigenetic mechanisms regulate NADPH oxidase- 4 expression in cellular senescence. Free Radic. Biol. Med. 79, 197-205. doi: 10.1016/j.freeradbiomed.2014.12.008

Schroder, K., and Tschopp, J. (2010). The inflammasomes. Cell 140, 821-832. doi: 10.1016/j.cell.2010.01.040

Shimada, K., Crother, T. R., Karlin, J., Dagvadorj, J., Chiba, N., Chen, S., et al. (2012). Oxidized mitochondrial DNA activates the NLRP3 inflammasome during apoptosis. Immunity 36, 401-414. doi: 10.1016/j.immuni.2012.01.009

Shin, H. S., Shin, M. S., Ahn, Y. B., Choi, B. Y., Nam, J. H., and Kim, H. D. (2016). Periodontitis is associated with cognitive impairment in elderly Koreans: results from the Yangpyeong cohort study. J. Am. Geriatr. Soc. 64, 162-167. doi: 10.1111/jgs.13781

Shirzad, A., Pouramir, M., Seyedmajidi, M., Jenabian, N., Bijani, A., and Motallebnejad, M. (2014). Salivary total antioxidant capacity and lipid peroxidation in patients with erosive oral lichen planus. J. Dent. Res. Dent. Clin. Dent. Prospects 8, 35-39. doi: 10.5681/joddd.2014.006

Shiva, A., and Arab, S. (2016). Evaluation of uric acid, total antioxidant and lipid peroxidation parameters in serum and saliva of patients with oral lichen planus. Glob. J. Health Sci. 8, 225-231. doi: 10.5539/gjhs.v8n12p225

Sima, C., Aboodi, G. M., Lakschevitz, F. S., Sun, C., Goldberg, M. B., and Glogauer, M. (2016). Nuclear factor erythroid 2-related factor 2 down-regulation in oral neutrophils is associated with periodontal oxidative damage and severe chronic periodontitis. Am. J. Pathol. 186, 1417-1426. doi: 10.1016/j.ajpath.2016.01.013

Slee, E. A., Harte, M. T., Kluck, R. M., Wolf, B. B., Casiano, C. A., Newmeyer, D. D., et al. (1999). Ordering the cytochrome c-initiated caspase cascade: hierarchical activation of caspases-2, $-3,-6,-7,-8$, and -10 in a caspase-9-dependent manner. J. Cell Biol. 144, 281-292. doi: 10.1083/jcb.144.2.281

Sobaniec, H., and Sobaniec-Lotowska, M. E. (2000). Morphological examinations of hard tissues of periodontium and evaluation of selected processes of lipid peroxidation in blood serum of rats in the course of experimental periodontitis. Med. Sci. Monit. 6, 875-881.

Soory, M. (2010). Oxidative stress induced mechanisms in the progression of periodontal diseases and cancer: a common approach to redox homeostasis? Cancers (Basel). 2, 670-692. doi: 10.3390/cancers 2020670

Sorbara, M. T., and Girardin, S. E. (2011). Mitochondrial ROS fuel the inflammasome. Cell Res. 21, 558-560. doi: 10.1038/cr.2011.20

Swomley, A. M., and Butterfield, D. A. (2015). Oxidative stress in Alzheimer disease and mild cognitive impairment: evidence from human data provided by redox proteomics. Arch. Toxicol. 89, 1669-1680. doi: 10.1007/s00204-015-1556-Z

Tabas, I., and Glass, C. K. (2013). Anti-inflammatory therapy in chronic disease: challenges and opportunities. Science 339, 166-172. doi: $10.1126 /$ science. 1230720

Takane, M., Sugano, N., Iwasaki, H., Iwano, Y., Shimizu, N., and Ito, K. (2002). New biomarker evidence of oxidative DNA damage in whole saliva from clinically healthy and periodontally diseased individuals. J. Periodontol. 73, 551-554. doi: 10.1902/jop.2002.73.5.551

Talalay, P., Dinkova-Kostova, A. T., and Holtzclaw, W. D. (2003). Importance of phase 2 gene regulation in protection against electrophile and reactive oxygen toxicity and carcinogenesis. Adv. Enzyme Regul. 43, 121-134. doi: 10.1016/S0065-2571(02)00038-9

Tamaki, N., Hayashida, H., Fukui, M., Kitamura, M., Kawasaki, K., Nakazato, M., et al. (2014). Oxidative stress and antibody levels to periodontal bacteria in adults: the Nagasaki Islands study. Oral Dis. 20, e49-e56. doi: 10.1111/odi.12127

Tanigawa, S., Fujii, M., and Hou, D. X. (2007). Action of Nrf2 and Keap1 in AREmediated NQO1 expression by quercetin. Free Radic. Biol. Med. 42, 1690-1703. doi: 10.1016/j.freeradbiomed.2007.02.017

Tariq, M., Manzoor, S., Ahmed, Q. L., Khalid, M., and Ashraf, W. (2013). NOX4 induces oxidative stress and apoptosis through upregulation of caspases 3 and
9 and downregulation of TIGAR in HCV-infected Huh-7 cells. Future Virol. 8, 707-716. doi: 10.2217/fvl.13.50

Theccanat, T., Philip, J. L., Razzaque, A. M., Ludmer, N., Li, J., Xu, X., et al. (2016). Regulation of cellular oxidative stress and apoptosis by $\mathrm{G}$ protein-coupled receptor kinase-2; The role of NADPH oxidase 4. Cell. Signal. 28, 190-203. doi: 10.1016/j.cellsig.2015.11.013

Tomofuji, T., Ekuni, D., Yamanaka, R., Kusano, H., Azuma, T., Sanbe, T., et al. (2007). Chronic administration of lipopolysaccharide and proteases induces periodontal inflammation and hepatic steatosis in rats. J. Periodontol. 78, 1999-2006. doi: 10.1902/jop.2007.070056

Tomofuji, T., Sanbe, T., Ekuni, D., Azuma, T., Irie, K., Maruyama, T., et al. (2008). Oxidative damage of rat liver induced by ligature-induced periodontitis and chronic ethanol consumption. Arch. Oral Biol. 53, 1113-1118. doi: 10.1016/j.archoralbio.2008.05.015

Tonetti, M. S. (2009). Periodontitis and risk for atherosclerosis: an update on intervention trials. J. Clin. Periodontol. 36(Suppl. 10), 15-19. doi: 10.1111/j.1600-051X.2009.01417.x

Tonetti, M. S., Jepsen, S., Jin, L., and Otomo-Corgel, J. (2017). Impact of the global burden of periodontal diseases on health, nutrition and wellbeing of mankind: a call for global action. J. Clin. Periodontol. 44, 456-462. doi: 10.1111/jcpe.12732

Trivedi, S., Lal, N., Mahdi, A. A., Singh, B., and Pandey, S. (2015). Association of salivary lipid peroxidation levels, antioxidant enzymes, and chronic periodontitis. Int. J. Periodontics Restorative Dent. 35, e14-e19. doi: $10.11607 /$ prd.2079

Tsao, R., and Li, H. (2012). "Antioxidant properties in vitro and in vivo: realistic assessments of efficacy of plant extracts," in Plant Sciences Reviews 2012, ed D. Hemming (Boston, MA: CABI International), 11-20.

Tucker, P. S., Scanlan, A. T., and Dalbo, V. J. (2015). Chronic kidney disease influences multiple systems: describing the relationship between oxidative stress, inflammation, kidney damage, and concomitant disease. Oxid. Med. Cell. Longev. 2015:806358. doi: 10.1155/2015/806358

Tvarijonaviciute, A., Aznar-Cayuela, C., Rubio, C. P., Ceron, J. J., and Lopez Jornet, P. (2017). Evaluation of salivary oxidate stress biomarkers, nitric oxide and C-reactive protein in patients with oral lichen planus and burning mouth syndrome. J. Oral Pathol. Med. 46, 387-392. doi: 10.1111/jop. 12522

Ueda, S., Masutani, H., Nakamura, H., Tanaka, T., Ueno, M., and Yodoi, J. (2002). Redox control of cell death. Antioxid. Redox Signal. 4, 405-414. doi: 10.1089/15230860260196209

Ungvari, Z., Orosz, Z., Labinskyy, N., Rivera, A., Xiangmin, Z., Smith, K., et al. (2007). Increased mitochondrial $\mathrm{H}_{2} \mathrm{O}_{2}$ production promotes endothelial NFkappaB activation in aged rat arteries. Am. J. Physiol. Heart Circ. Physiol. 293, H37-H47. doi: 10.1152/ajpheart.01346.2006

Ustinova, A. A., and Riabinin, V. E. (2003). Effect of chronic $\gamma$-irradiation on lipid peroxidation in CBA mouse blood serum. Radiats. Biol. Radioecol. 43, 459-463.

Vallet, P., Charnay, Y., Steger, K., Ogier-Denis, E., Kovari, E., Herrmann, F., et al. (2005). Neuronal expression of the NADPH oxidase NOX4, and its regulation in mouse experimental brain ischemia. Neuroscience 132, 233-238. doi: 10.1016/j.neuroscience.2004.12.038

Vendrov, A. E., Vendrov, K. C., Smith, A., Yuan, J., Sumida, A., Robidoux, J., et al. (2015). NOX4 NADPH oxidase-dependent mitochondrial oxidative stress in aging-associated cardiovascular disease. Antioxid. Redox Signal. 23, 1389-1409. doi: $10.1089 /$ ars.2014.6221

Venugopal, R., and Jaiswal, A. K. (1996). Nrf1 and Nrf2 positively and c-Fos and Fral negatively regulate the human antioxidant response element-mediated expression of NAD(P)H:quinone oxidoreductase1 gene. Proc. Natl. Acad. Sci. U.S.A. 93, 14960-14965. doi: 10.1073/pnas.93.25.14960

Vogel, C. F., Khan, E. M., Leung, P. S., Gershwin, M. E., Chang, W. L., $\mathrm{Wu}$, D., et al. (2014). Cross-talk between aryl hydrocarbon receptor and the inflammatory response: a role for nuclear factor- $\kappa$ B. J. Biol. Chem. 289, 1866-1875. doi: 10.1074/jbc.M113.505578

Wakabayashi, N., Itoh, K., Wakabayashi, J., Motohashi, H., Noda, S., Takahashi, S., et al. (2003). Keap1-null mutation leads to postnatal lethality due to constitutive Nrf2 activation. Nat. Genet. 35, 238-245. doi: 10.1038/ng1248

Wen, H., Gris, D., Lei, Y., Jha, S., Zhang, L., Huang, M. T., et al. (2011). Fatty acid-induced NLRP3-ASC inflammasome activation interferes with insulin signaling. Nat. Immunol. 12, 408-415. doi: 10.1038/ni.2022 
Wu, F., Chen, Y., Demmer, R. T., Parvez, F., Paul, R. R., Shaheen, I., et al. (2016). Periodontal diseases and carotid intima-media thickness in Bangladesh. J. Clin. Periodontol. 43, 909-917. doi: 10.1111/jcpe. 12597

Xue, F., Shu, R., and Xie, Y. (2015). The expression of NLRP3, NLRP1 and AIM2 in the gingival tissue of periodontitis patients: RT-PCR study and immunohistochemistry. Arch. Oral Biol. 60, 948-958. doi: 10.1016/j.archoralbio.2015.03.005

Yamaguchi, Y., Kurita-Ochiai, T., Kobayashi, R., Suzuki, T., and Ando, T. (2017). Regulation of the NLRP3 inflammasome in Porphyromonas gingivalis-accelerated periodontal disease. Inflamm. Res. 66, 59-65. doi: 10.1007/s00011-016-0992-4

Yu, R., Lei, W., Mandlekar, S., Weber, M. J., Der, C. J., Wu, J., et al. (1999). Role of a mitogen-activated protein kinase pathway in the induction of phase II detoxifying enzymes by chemicals. J. Biol. Chem. 274, 27545-27552. doi: 10.1074/jbc.274.39.27545

Zanella, S. M., Pereira, S. S., Barbisan, J. N., Vieira, L., Saba-Chujfi, E., Haas, A. N., et al. (2016). Periodontal disease, tooth loss and coronary heart disease assessed by coronary angiography: a cross-sectional observational study. J. Periodont. Res. 51, 221-227. doi: 10.1111/jre.12301

Zeng, X. T., Leng, W. D., Lam, Y. Y., Yan, B. P., Wei, X. M., Weng, H., et al. (2016). Periodontal disease and carotid atherosclerosis: a meta-analysis of 17,330 participants. Int. J. Cardiol. 203, 1044-1051. doi: 10.1016/j.ijcard.2015. 11.092

Zhang, L., Sheppard, O. R., Shah, A. M., and Brewer, A. C. (2008). Positive regulation of the NADPH oxidase NOX4 promoter in vascular smooth muscle cells by E2F. Free Radic. Biol. Med. 45, 679-685. doi: 10.1016/j.freeradbiomed.2008.05.019
Zhang, S., Qin, C., and Safe, S. H. (2003). Flavonoids as aryl hydrocarbon receptor agonists/antagonists: effects of structure and cell context. Environ. Health Perspect. 111, 1877-1882. doi: 10.1289/ehp.6322

Zhang, X., Wang, G., Gurley, E. C., and Zhou, H. (2014). Flavonoid apigenin inhibits lipopolysaccharide-induced inflammatory response through multiple mechanisms in macrophages. PLoS ONE 9:e107072. doi: 10.1371/journal.pone.0107072

Zhao, D., Wu, Y., Zhuang, J., Xu, C., and Zhang, F. (2016). Activation of NLRP1 and NLRP3 inflammasomes contributed to cyclic stretch-induced pyroptosis and release of IL-1 $\beta$ in human periodontal ligament cells. Oncotarget 7 , 68292-68302. doi: 10.18632/oncotarget.11944

Zhong, Z., Zhai, Y., Liang, S., Mori, Y., Han, R., Sutterwala, F. S., et al (2013). TRPM2 links oxidative stress to NLRP3 inflammasome activation. Nat. Commun. 4:1611. doi: 10.1038/ncomms 2608

Zuo, Y., Xiang, B., Yang, J., Sun, X., Wang, Y., Cang, H., et al. (2009). Oxidative modification of caspase- 9 facilitates its activation via disulfide-mediated interaction with Apaf-1. Cell Res. 19, 449-457. doi: 10.1038/cr.2009.19

Conflict of Interest Statement: The authors declare that the research was conducted in the absence of any commercial or financial relationships that could be construed as a potential conflict of interest.

Copyright $\odot 2017$ Kumar, Teoh, Das and Mahakknaukrauh. This is an open-access article distributed under the terms of the Creative Commons Attribution License (CC $B Y)$. The use, distribution or reproduction in other forums is permitted, provided the original author(s) or licensor are credited and that the original publication in this journal is cited, in accordance with accepted academic practice. No use, distribution or reproduction is permitted which does not comply with these terms. 